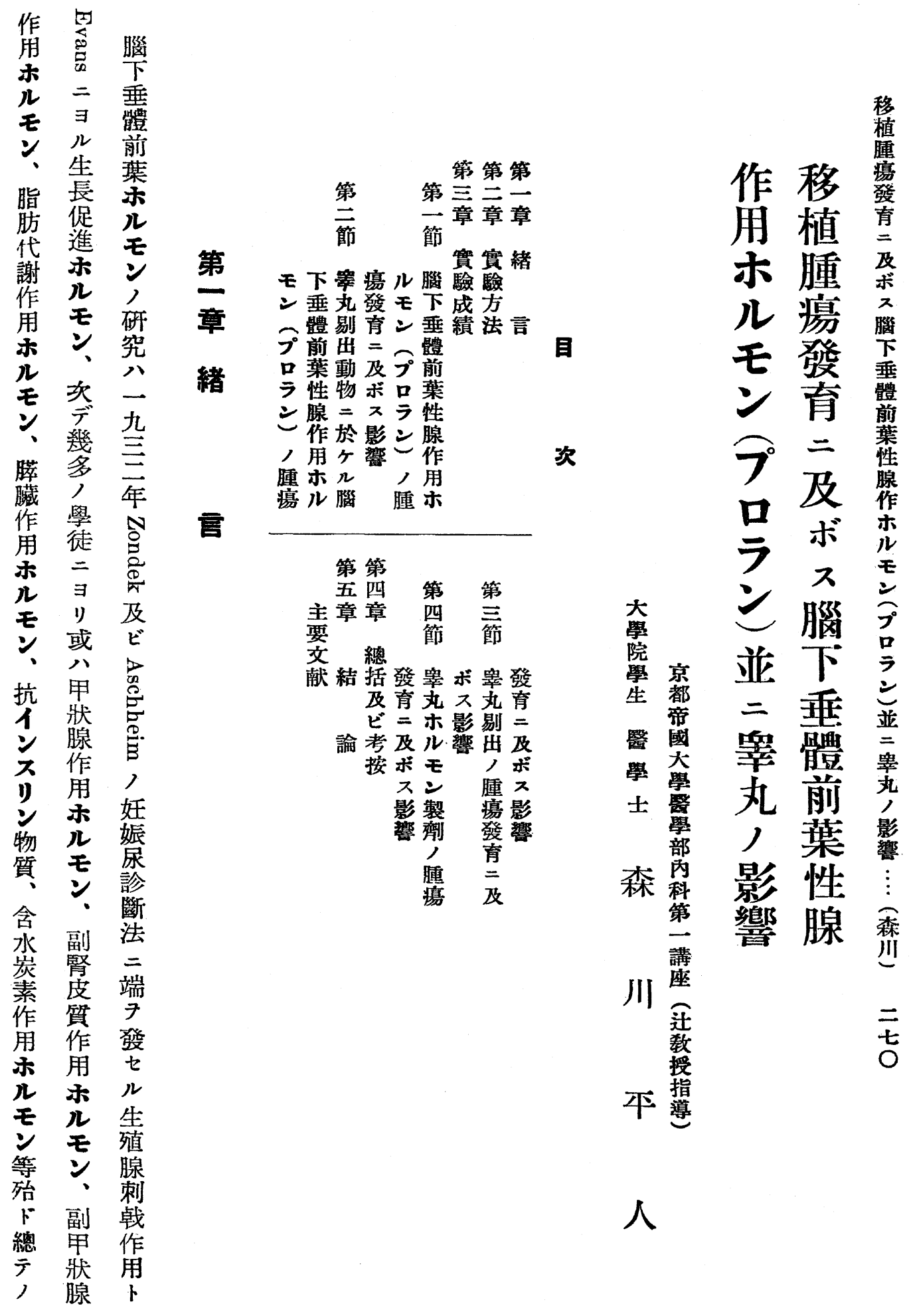




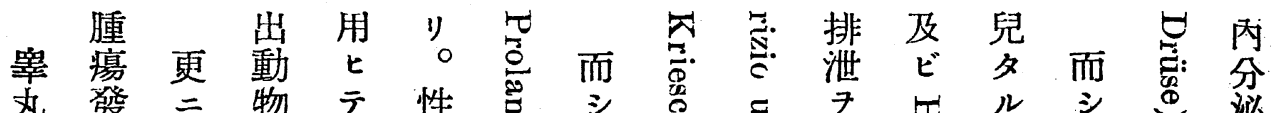

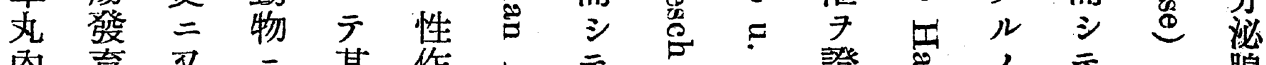

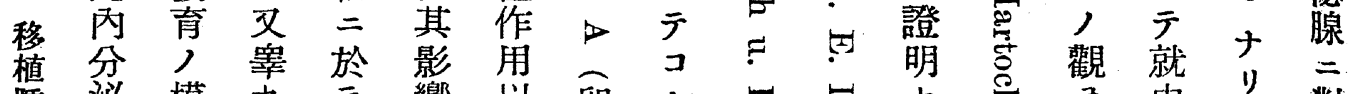

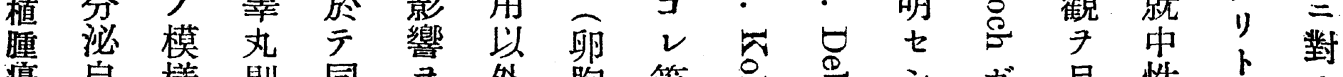

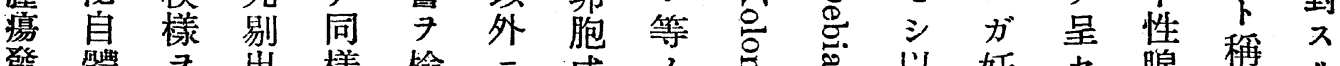
發體 7 出樣 憸云成了,

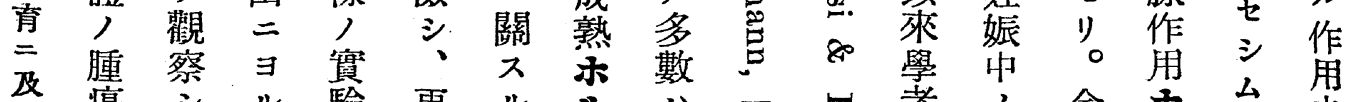

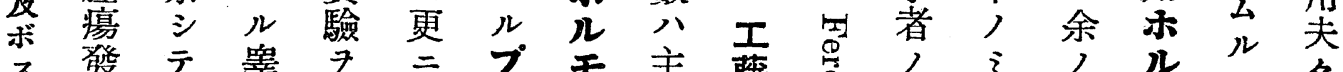

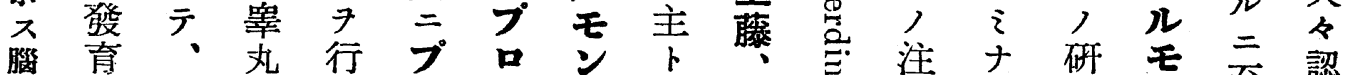
下

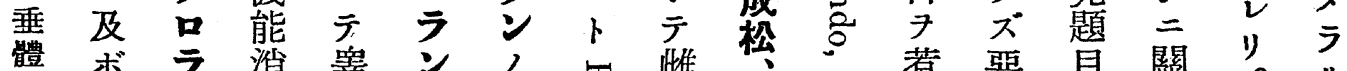

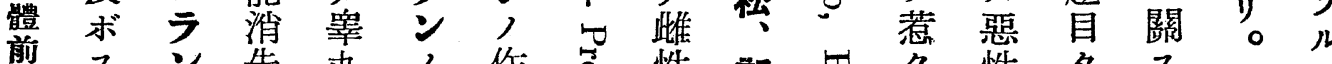

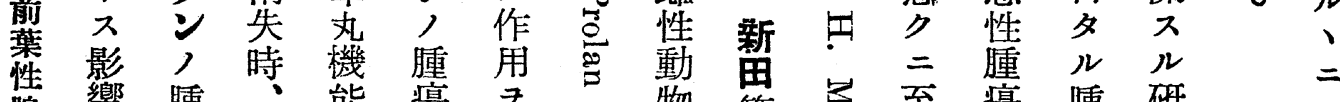
腺 響 腫

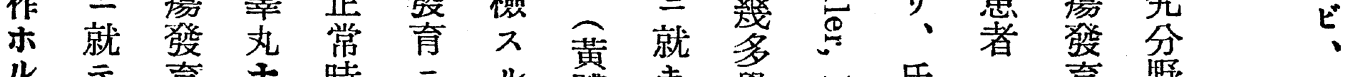

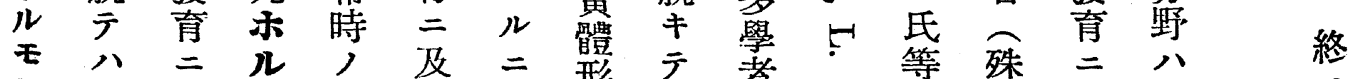
最及王プ ボハ形實者。少二對最二

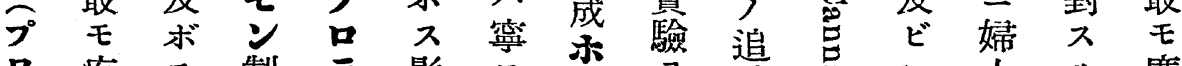

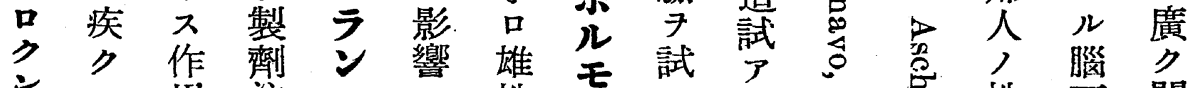

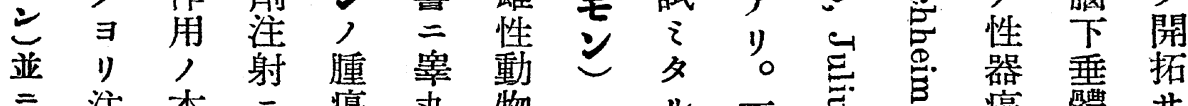

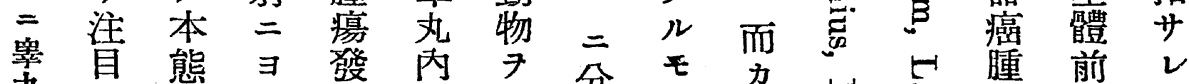
貟自態 影 究 解 钼

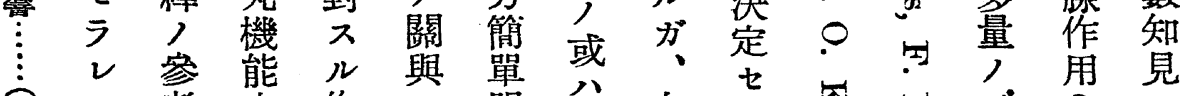

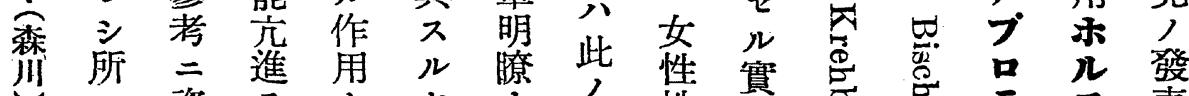

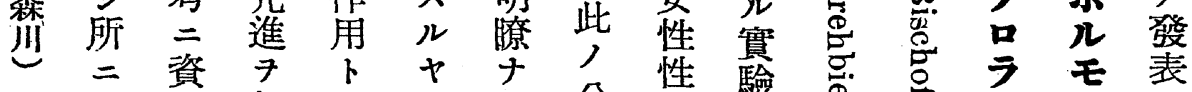

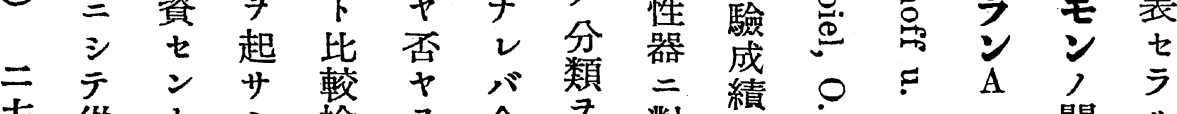

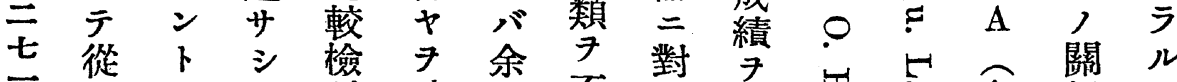
甲 七 $>$ 討 確

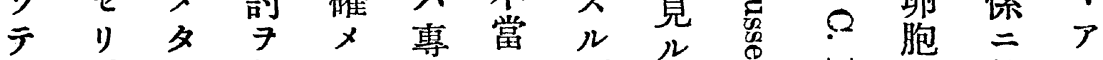

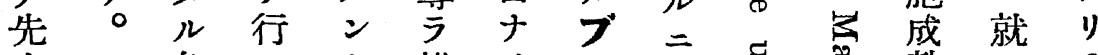

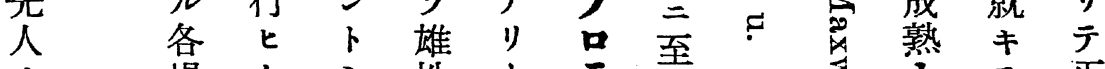

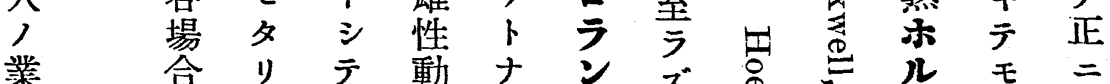

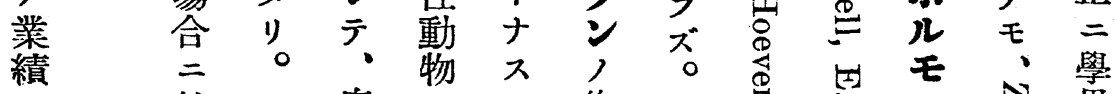

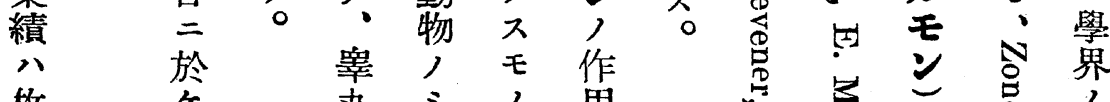
枚年方, 用 各 


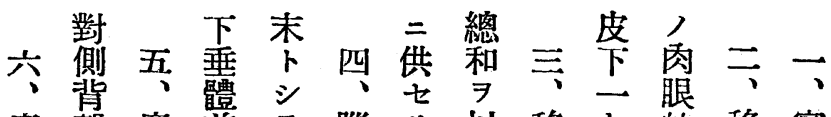
睪部睪揱テ腦り。䔟々的移實

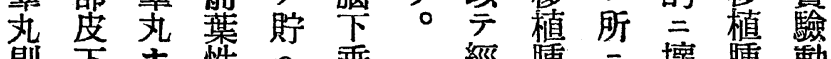

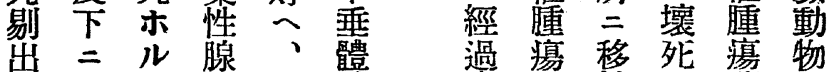

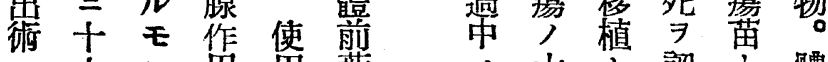

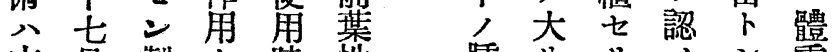

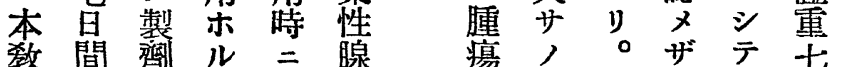

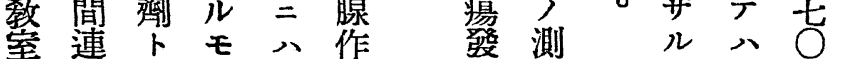
從續 シ 每角笲定周京方

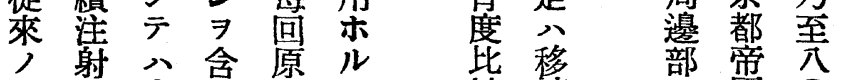

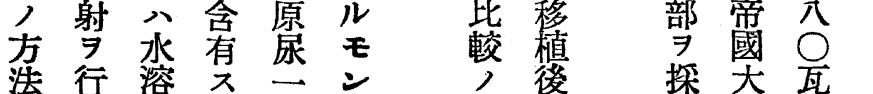

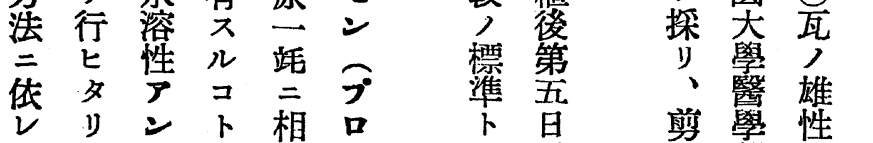

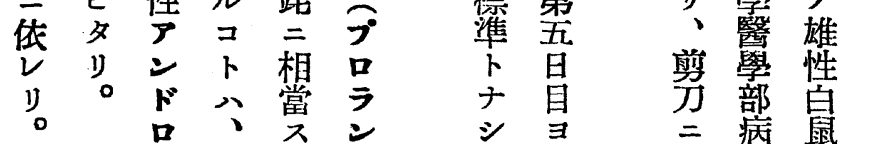

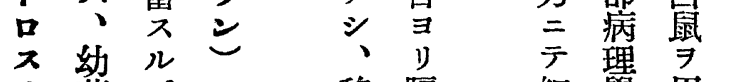
天若プノ移隔細學角 学索

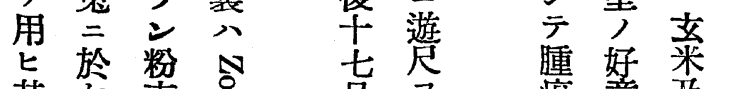

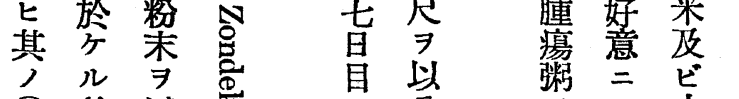
○效隇

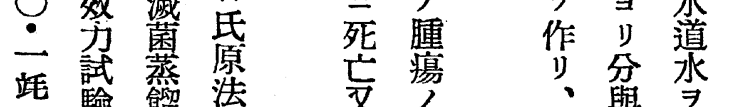

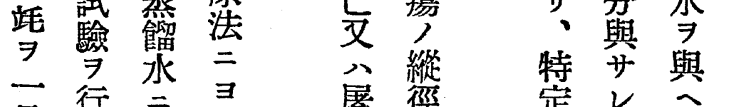

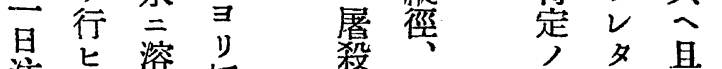

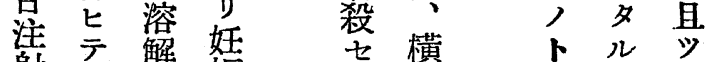

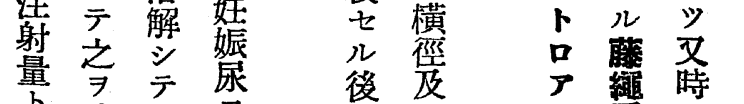

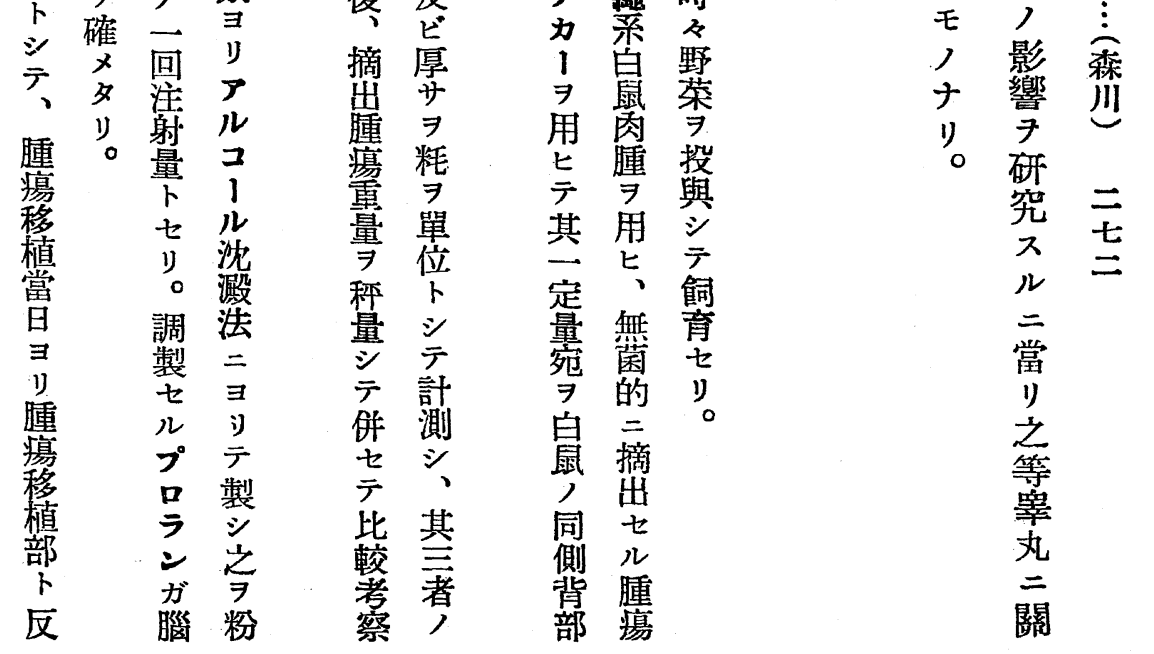


第一丧 體 照 群

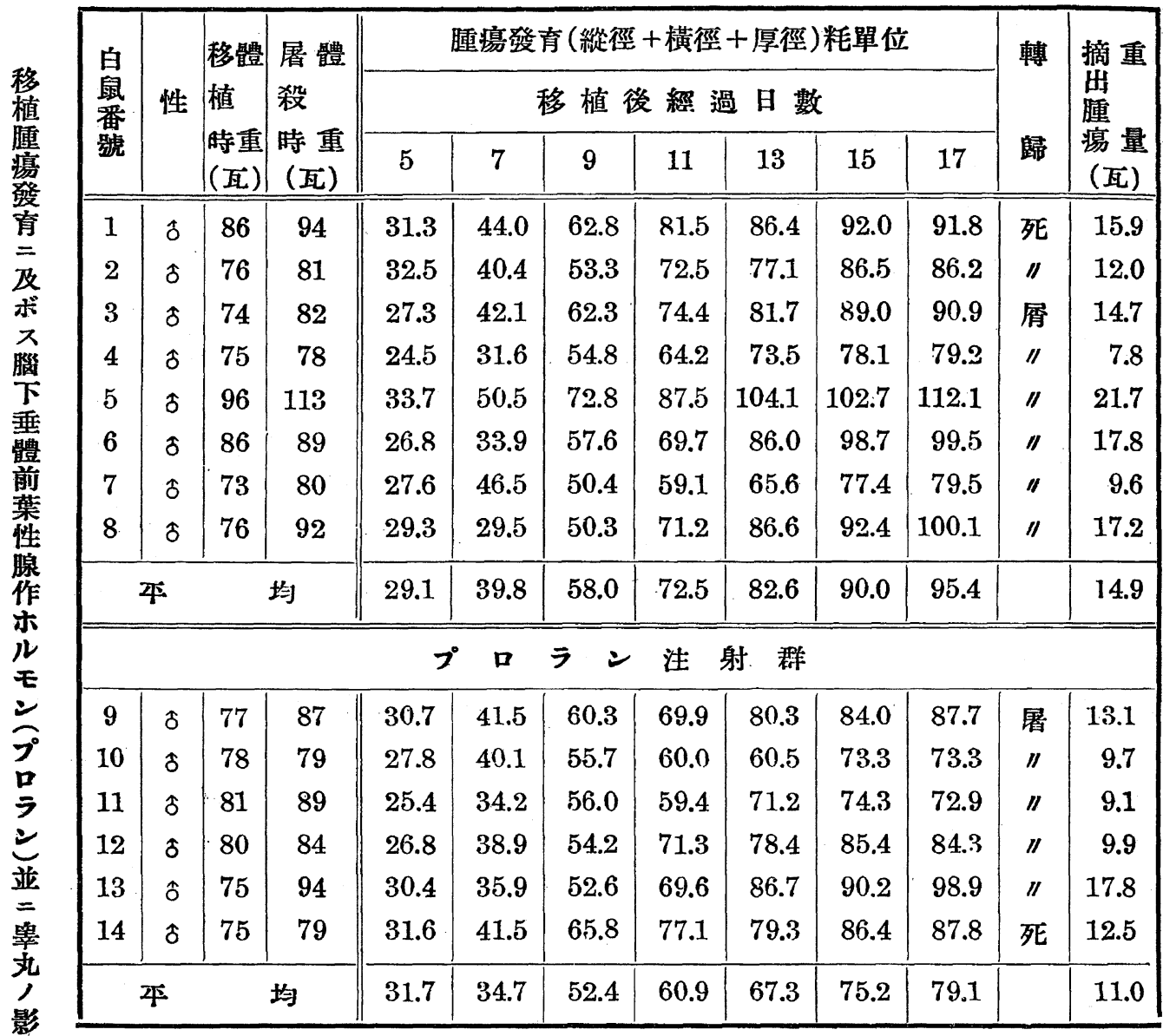

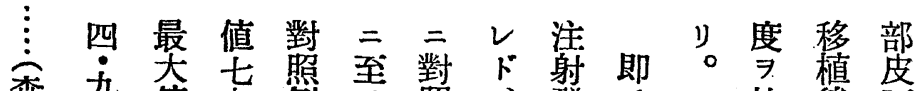

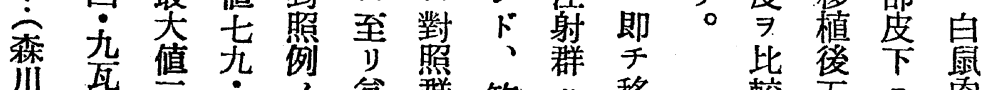

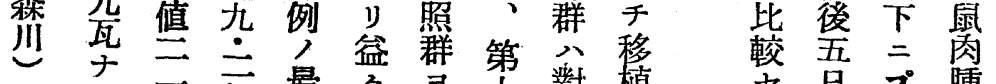

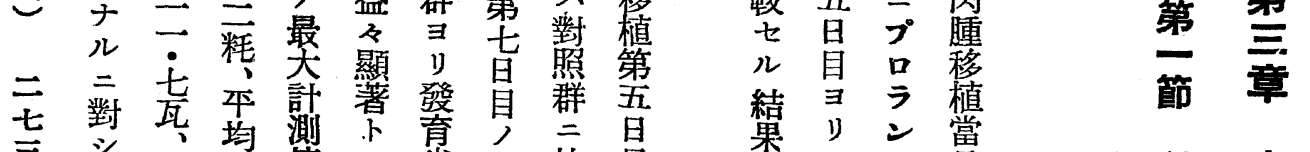

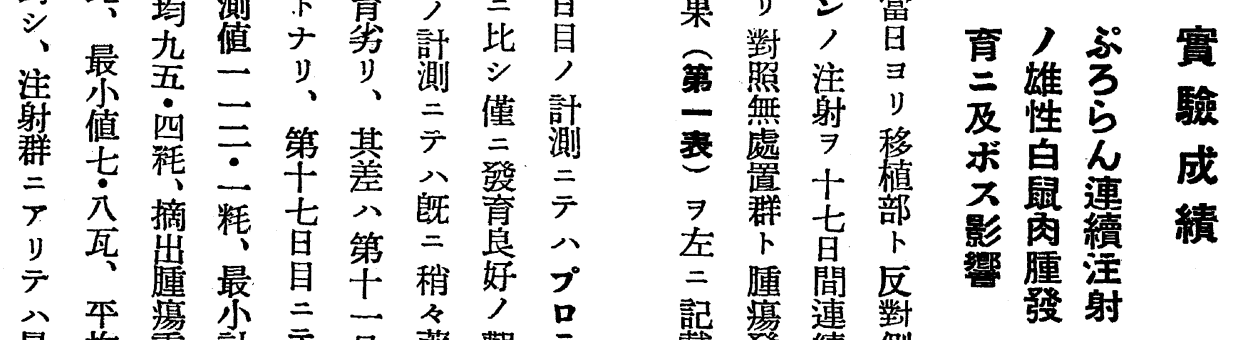

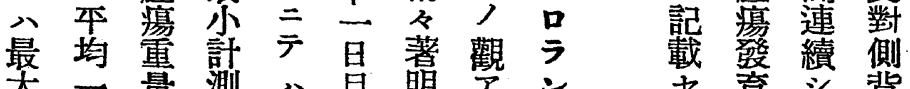


第二表 辠丸剔出群

\begin{tabular}{|c|c|c|c|c|c|c|c|c|c|c|c|c|}
\hline \multirow{3}{*}{$\begin{array}{l}\text { 皇 } \\
\text { 鼠 } \\
\text { 號 }\end{array}$} & \multirow{3}{*}{ 性 } & \multirow{3}{*}{$\begin{array}{l}\text { 移體 } \\
\text { 植 } \\
\text { 時重 } \\
\text { (桼) }\end{array}$} & \multirow{3}{*}{$\begin{array}{l}\text { 屠體 } \\
\text { 殺 } \\
\text { 時重 } \\
\text { (酉) } \\
\end{array}$} & \multicolumn{7}{|c|}{ 畽瘍發育 (縱徑＋横徑＋厚彺)籷單位 } & \multirow{3}{*}{$\begin{array}{l}\text { 轉 } \\
\text { 歸 }\end{array}$} & \multirow{3}{*}{\begin{tabular}{|l} 
摘 重 \\
出 \\
腫 \\
痬 量 \\
$($ 互)
\end{tabular}} \\
\hline & & & & \multicolumn{7}{|c|}{ 移 植 後 經 過 日 數 } & & \\
\hline & & & & 5 & 7 & 9 & 11 & 13 & 15 & 17 & & \\
\hline 1 & $\hat{o}$ & 84 & 101 & 31.5 & 47.0 & 64.8 & 80.9 & 91.7 & 98.0 & 114.6 & 屠 & 25.6 \\
\hline 2 & $\delta$ & 87 & 87 & 36.6 & 69.1 & 89.2 & 96.8 & 106.3 & 108.7 & 108.7 & 死 & 19.2 \\
\hline 3 & 今 & 75 & 82 & 24.7 & 26.8 & 30.5 & 33.5 & 52.6 & 63.1 & 79.5 & 屠 & 10.7 \\
\hline 4 & $\hat{\delta}$ & 78 & 92 & 34.2 & 49.0 & 51.2 & 70.9 & 87.9 & 105.5 & 114.6 & $\|$ & 24.6 \\
\hline 5 & $\delta$ & 80 & 91 & 27.2 & 29.8 & 47.6 & 62.5 & 74.4 & 87.0 & 92.7 & $\|$ & 19.0 \\
\hline 6 & $\hat{o}$ & 79 & 83 & 28.1 & 33.3 & 40.6 & 53.4 & 72.8 & 90.3 & 91.0 & $\|$ & 14.3 \\
\hline \multicolumn{3}{|c|}{ 本 } & 均 & 30.4 & 42.5 & 54.0 & 66.3 & 81.0 & 92.1 & 100.2 & & 18.9 \\
\hline \multicolumn{13}{|c|}{ 䅴丸剔 出プロラン注射群 } \\
\hline 7 & $\hat{\delta}$ & 84 & 93 & 30.5 & 43.4 & 58.5 & 77.3 & 79.2 & 87.6 & 102.3 & 屠 & 20.4 \\
\hline 8 & $\delta$ & 80 & 85 & 28.1 & 50.5 & 69.0 & 78.8 & 85.2 & 93.5 & 90.7 & "I & 19.0 \\
\hline 9 & $\hat{o}$ & 87 & 95 & 24.9 & 33.9 & 51.6 & 69.7 & 81.7 & 87.7 & 98.7 & "I & 17.8 \\
\hline 10 & $\hat{\delta}$ & 76 & 74 & 22.9 & 24.6 & 25.0 & 45.4 & 56.9 & 61.9 & 68.4 & "I & 8.1 \\
\hline 11. & $\hat{\jmath}$ & 76 & 86 & 26.8 & 29.8 & 42.8 & 53.1 & 70.7 & 81.3 & 95.5 & $\not 1$ & 16.5 \\
\hline 12 & $\hat{\delta}$ & 75 & 90 & 25.7 & 30.5 & 40.1 & 54.2 & 70.8 & 82.6 & 87.3 & $\|$ & 12.3 \\
\hline \multicolumn{2}{|c|}{ 平 } & & I小 & 26.5 & 35.5 & 47.9 & 57.1 & 70.6 & 78.4 & 86.9 & & 15.2 \\
\hline
\end{tabular}

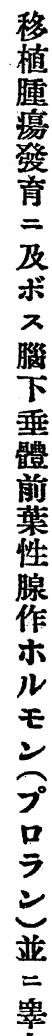

目第粍台日步射タ移 シ

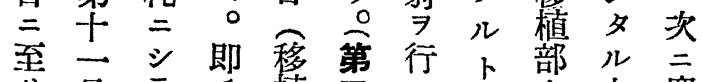

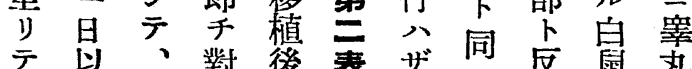

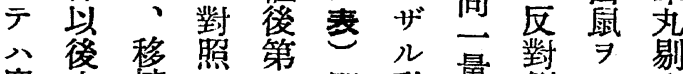

睪资植照即動量側三出

丸第後平白平物陊背群

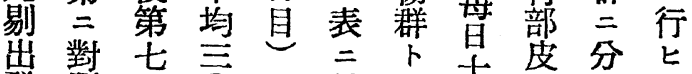

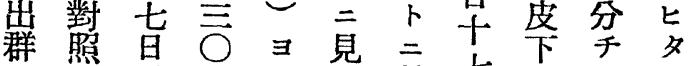

最, 第見慨如就早

最差旮粍既如努間

計笑 $=$ 比輕注癔㴬

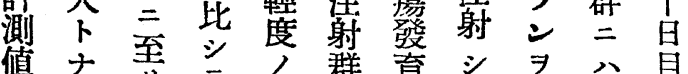

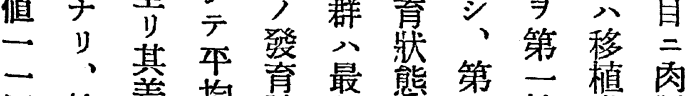

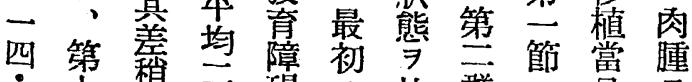

六十相六碍人比群二昌 7

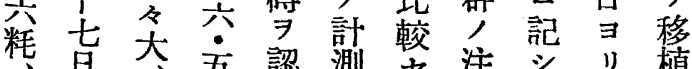

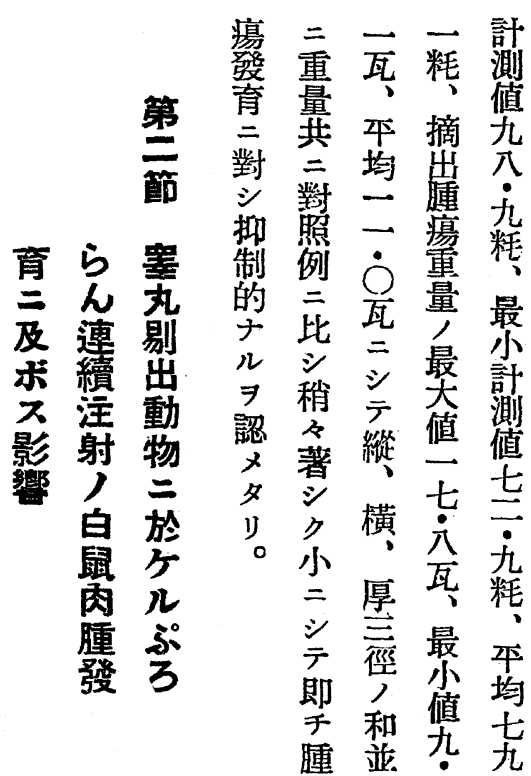


第三表 睪丸剔出群

\begin{tabular}{|c|c|c|c|c|c|c|c|c|c|c|c|c|}
\hline \multirow{3}{*}{$\begin{array}{l}\text { 泉 } \\
\text { 鼠 } \\
\text { 號 }\end{array}$} & \multirow{3}{*}{ 性 } & \multirow{3}{*}{$\begin{array}{l}\text { 移體 } \\
\text { 植 } \\
\text { 時重 } \\
(\text { 互 })\end{array}$} & \multirow{3}{*}{$\begin{array}{l}\text { 屠圆 } \\
\text { 殺 } \\
\text { 時重 } \\
\text { (酉) }\end{array}$} & \multicolumn{7}{|c|}{ 腫瘍發育 (縱徑＋横徑＋厚徑)粍單位 } & \multirow{3}{*}{$\begin{array}{l}\text { 轉 } \\
\text { 蹛 }\end{array}$} & \multirow{3}{*}{\begin{tabular}{|l} 
摘 重 \\
出 \\
腫 \\
痬 量 \\
(瓨)
\end{tabular}} \\
\hline & & & & \multicolumn{7}{|c|}{ 移 植 後 經 過 日 數 } & & \\
\hline & & & & 5 & 7 & 9 & 11 & 13 & 15 & 17 & & \\
\hline 1 & $\hat{\delta}$ & 78 & 101 & 31.5 & .47 .0 & 64.8 & 80.9 & 91.7 & 98.0 & 114.6 & 屠 & 25.6 \\
\hline 2 & $\delta$ & 80 & 84 & 36.6 & 69.1 & 39.2 & 96.8 & 106.3 & 108.7 & 108.7 & 死 & 19.2 \\
\hline 3 & $\delta$ & 69 & 88 & 24.7 & 26.8 & 30.5 & 33.5 & 52.6 & 63.1 & 79.5 & 屠 & 10.7 \\
\hline 4 & $\hat{o}$ & 70 & 92 & 34.2 & 49.0 & 51.2 & 70.9 & 87.9 & 105.5 & 114.6 & "I & 24.6 \\
\hline 5 & $\delta$ & 78 & 91 & 27.2 & 29.8 & 47.6 & 62.5 & 74.4 & 87.0 & 92.7 & II & 19.0 \\
\hline 6 & $\hat{o}$ & 72 & 83 & 28.1 & 33.3 & 40.6 & 53.4 & 72.8 & 90.3 & 94.0 & " & 14.3 \\
\hline \multicolumn{3}{|c|}{ 平 } & 均 & 30.4 & 42.5 & 54.0 & 66.3 & 81.0 & 92.1 & 102.2 & & 18.9 \\
\hline \multicolumn{13}{|c|}{ 對 } \\
\hline 7 & $\hat{\delta}$ & 71 & 95 & 29.2 & 42.4 & 62.5 & 79.2 & 89.3 & 95.6 & 106.6 & 屠 & 21.4 \\
\hline 8 & $\hat{\delta}$ & 73 & 104 & 33.7 & 56.5 & 72.8 & 87.5 & 104.1 & 102.7 & 112.1 & $\|$ & 21.8 \\
\hline 9 & $\delta$ & 73 & 85 & 26.3 & 37.0 & 44.4 & 54.3 & 65.0 & 85.6 & 87.1 & " & 11.5 \\
\hline 10 & $\delta$ & 82 & 110 & 28.2 & 46.2 & 68.0 & 82.7 & 91.6 & 102.7 & 114.9 & "I & 23.9 \\
\hline 11 & $\delta$ & 71 & 81 & 25.2 & 29.4 & 32.0 & 60.4 & 73.5 & 87.3 & 94.0 & "I & 15.7 \\
\hline 12 & $\hat{\delta}$ & 70 & 78 & 28.5 & 28.3 & 46.6 & 47.2 & 53.4 & 73.5 & 90.3 & $"$ & 14.6 \\
\hline \multicolumn{2}{|c|}{ 平 } & & 均 & 28.5 & 39.9 & 54.4 & 68.5 & 79.5 & 90.2 & 100.8 & & 18.1 \\
\hline
\end{tabular}

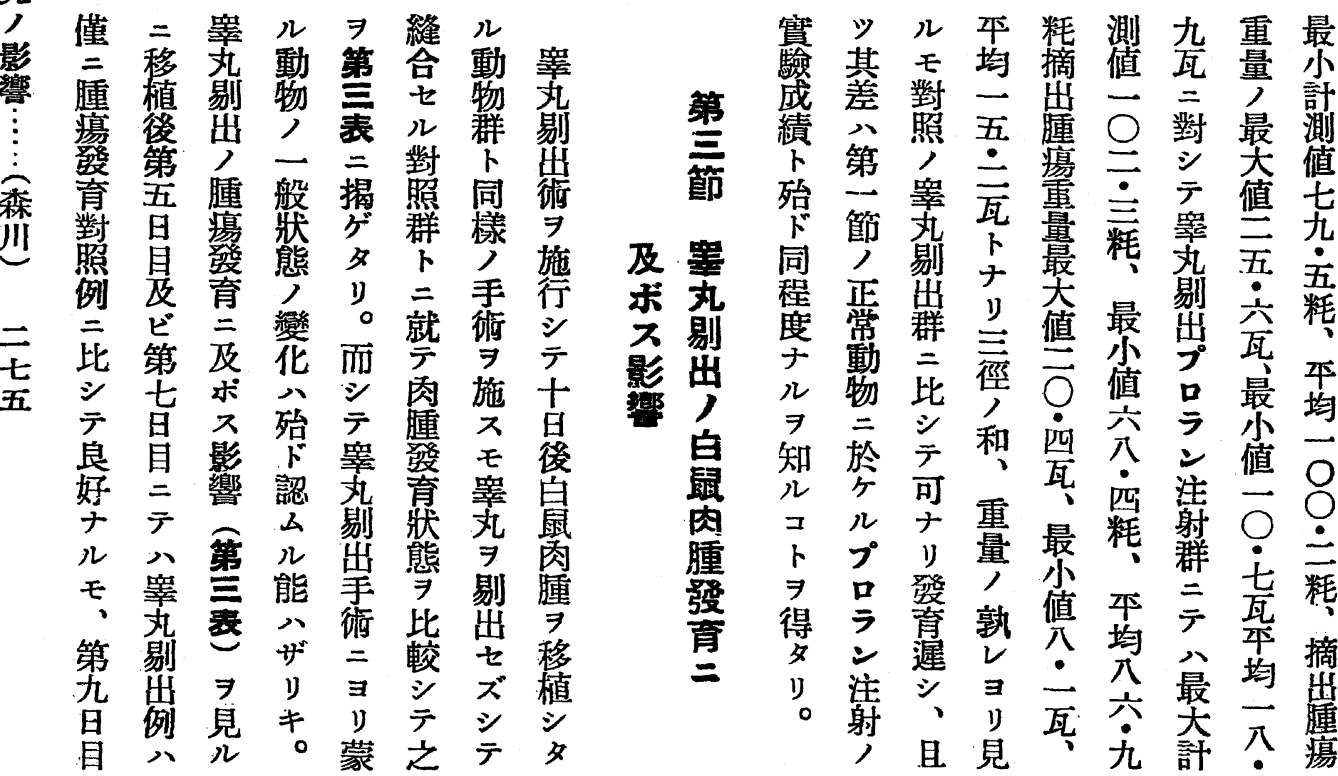


苇四表 對 照 群

\begin{tabular}{|c|c|c|c|c|c|c|c|c|c|c|c|c|}
\hline \multirow{3}{*}{$\begin{array}{l}\text { 泉 } \\
\text { 鼠 } \\
\text { 番 } \\
\text { 號 }\end{array}$} & \multirow{3}{*}{ 性 } & \multirow{3}{*}{\begin{tabular}{|l}
$\mid$ 手體 \\
術 \\
時重 \\
(䑁)
\end{tabular}} & \multirow{3}{*}{$\begin{array}{l}\text { 屠體 } \\
\text { 殺 } \\
\text { 時重 } \\
\text { (宜) }\end{array}$} & \multicolumn{7}{|c|}{ 腫湯發育(縱徑＋橫徑＋厚徑粍單位) } & \multirow{3}{*}{$\begin{array}{l}\text { 轉 } \\
\text { 歸 }\end{array}$} & \multirow{3}{*}{$\begin{array}{l}\text { 摘重 } \\
\text { 嬞 } \\
\text { 場 量 } \\
\text { (瓦) }\end{array}$} \\
\hline & & & & \multicolumn{7}{|c|}{ 移植後䋔過日數 } & & \\
\hline & & & & 5 & 7 & 9 & 11 & 13 & 15 & 17 & & \\
\hline 1 & $\delta$ & 78 & 94 & 26.3 & 32.7 & 41.5 & 52.7 & 61.3 & 74.0 & 83.7 & 屠 & 13.8 \\
\hline 2 & $\hat{o}$ & 75 & 80 & 28.2 & 35.4 & 48.7 & 62.5 & 70.8 & 81.3 & 92.1 & $\|$ & 15.4 \\
\hline 3 & $\hat{o}$ & 81 & 107 & 32.1 & 40.6 & 53.5 & 67.3 & 80.2 & 92.7 & 103.1 & " & 19.1 \\
\hline 4 & $\hat{o}$ & 84 & 90 & - & 28.5 & 35.7 & 46.1 & 56.9 & 65.7 & 79.6 & "I & 13.2 \\
\hline$\check{0}$ & $\delta$ & 78 & 70 & 27.1 & 34.6 & 46.3 & 60.0 & 69.8 & 78.4 & 89.3 & " & 14.7 \\
\hline 6 & $\delta$ & 77 & 97 & 30.4 & 40.0 & 51.4 & 66.6 & 74.3 & 83.5 & 95.5 & "I & 17.0 \\
\hline & 平 & & 均 & 29.2 & 35.3 & 46.2 & 59.0 & 68.9 & 79.3 & 90.6 & & 15.5 \\
\hline \multicolumn{13}{|c|}{ アンドロスチン注射群 } \\
\hline 7 & $\delta$ & 78 & 90 & 29.3 & 36.0 & 48.7 & 61.2 & 70.0 & 81.0 & 93.2 & 屠 & 16.4 \\
\hline 8 & $\hat{o}$ & 83 & 97 & 27.1 & 34.5 & 42.0 & 55.4 & 62.8 & 74.0 & 83.3 & "I & 14.3 \\
\hline 9 & $\delta$ & 75 & 104 & 31.5 & 40.5 & 54.5 & 68.3 & 80.2 & 94.3 & 106.7 & "I & 19.8 \\
\hline 10 & $\hat{o}$ & 81 & 85 & 29.5 & 36.7 & 46.3 & 58.9 & 66.4 & 74.3 & 79.9 & "I & 13.8 \\
\hline 11 & $\delta$ & 80 & 83 & 29.4 & 37.3 & 46.1 & 59.8 & 69.4 & 78.3 & 91.4 & "I & 14.7 \\
\hline 12 & $\delta$ & 73 & 94 & 31.0 & 42.7 & 53.3 & 63.9 & 71.7 & 80.1 & 90.3 & " & 15.4 \\
\hline \multicolumn{2}{|c|}{ 平 } & \multicolumn{2}{|r|}{ 均 } & 29.6 & 37.9 & 48.5 & 61.2 & 69.9 & 80.0 & 90.8 & & 15.9 \\
\hline
\end{tabular}

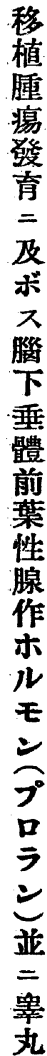

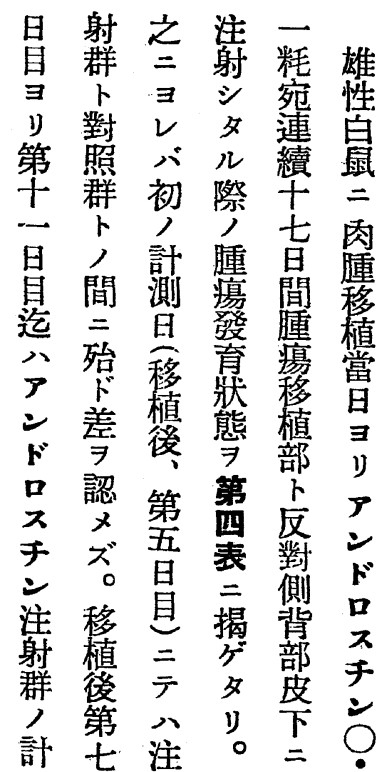

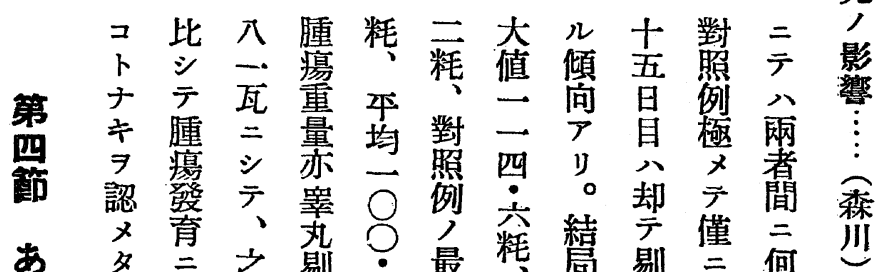

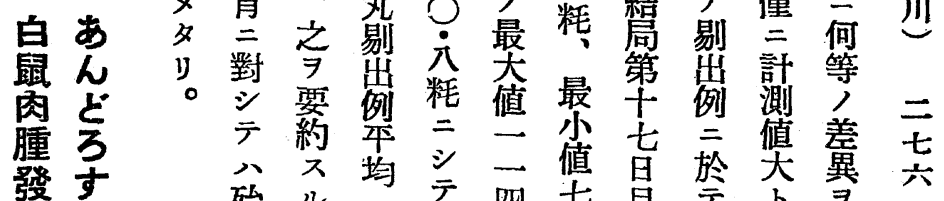

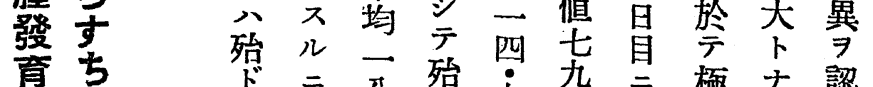

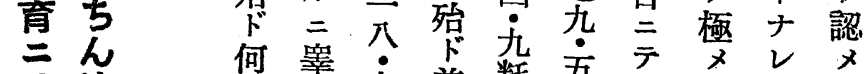

及蓮 等菱杂差粍吾テ粍

ボ續人剔瓦灵最䚽睪㒖モ。

ス注作出對認最平势第第

影射 角例照

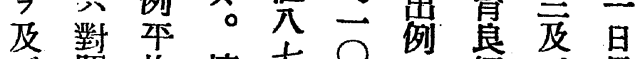

ボ照均摘七@方好 ビ自 ス $=$ 一出 


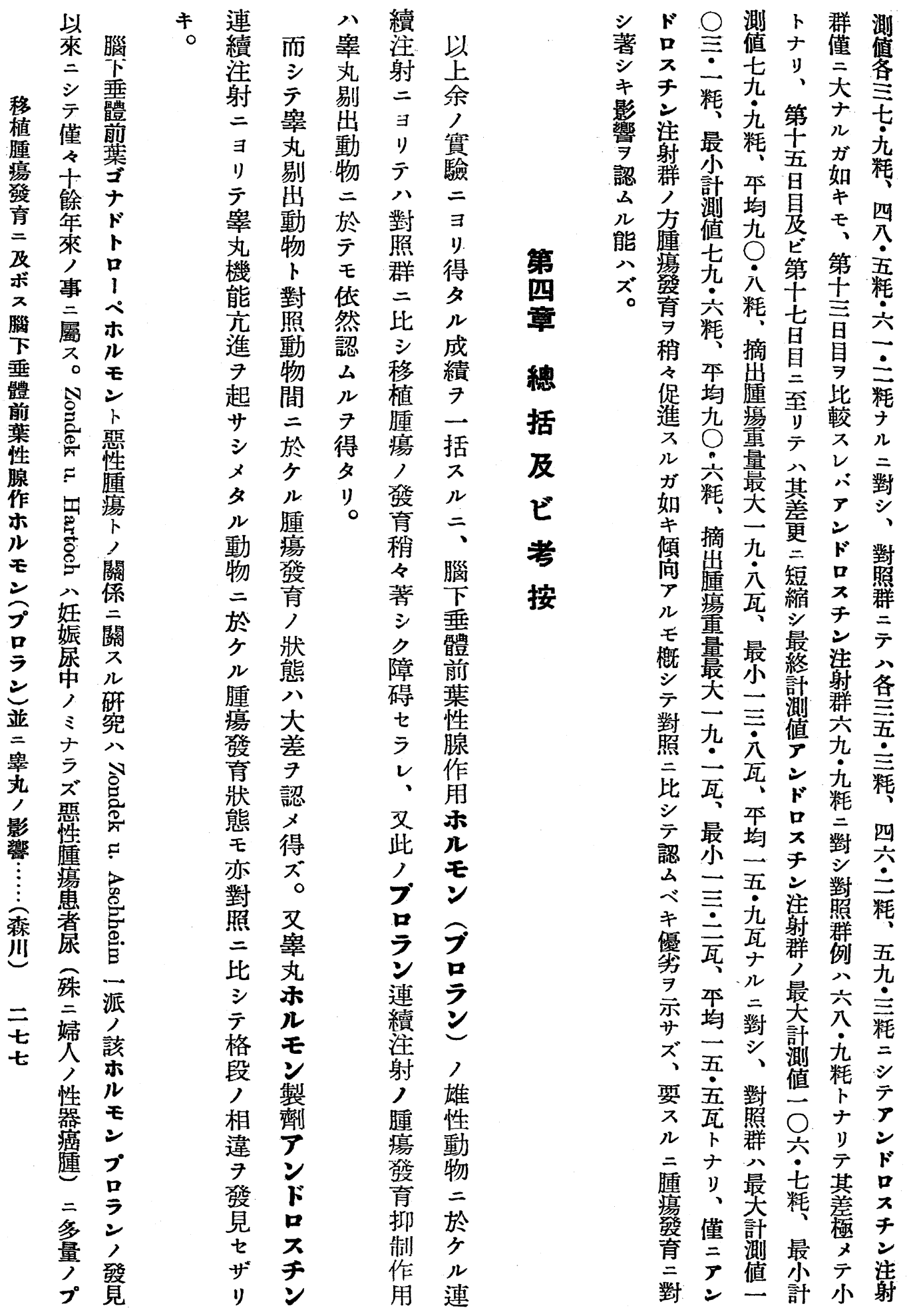


影全裙 論

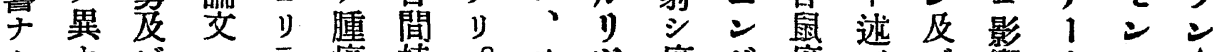

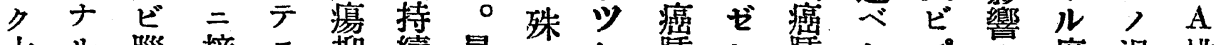
大儿腦 接モ抑續最

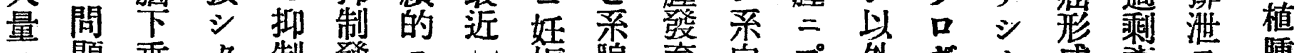
三題重 タ 制登

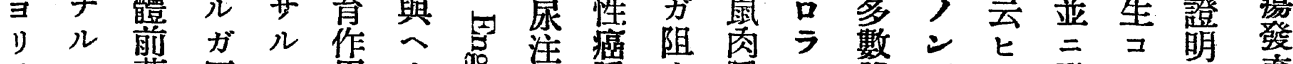

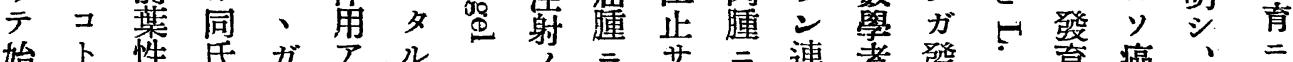

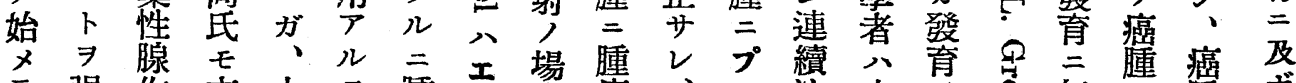

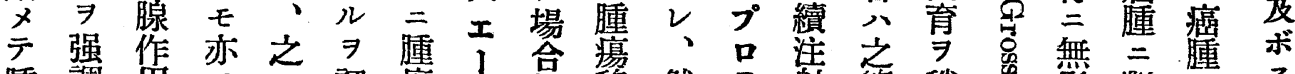

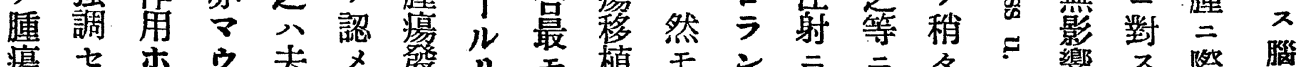
瘍七ホウ去 發り。ルモ゙

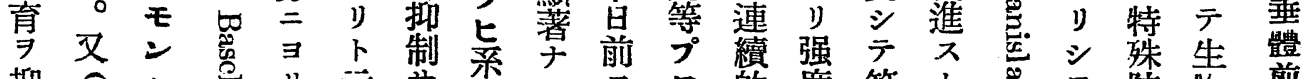

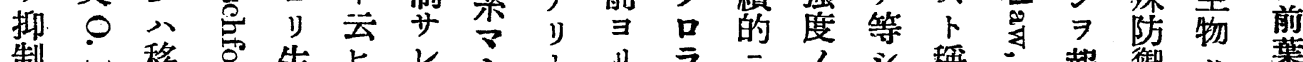
制移宫生

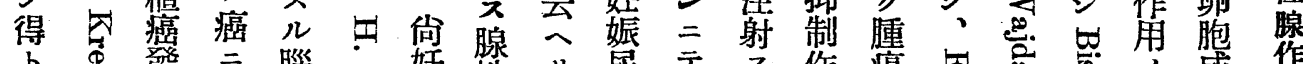

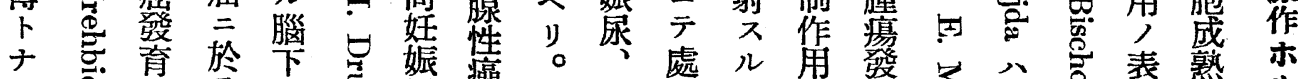

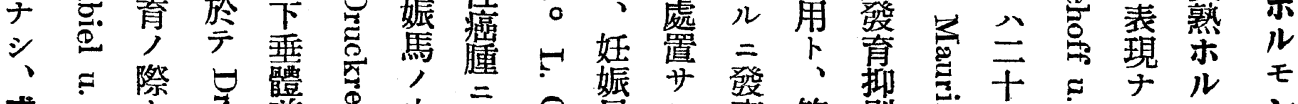
成

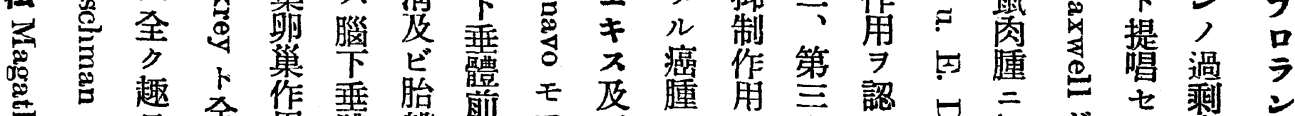

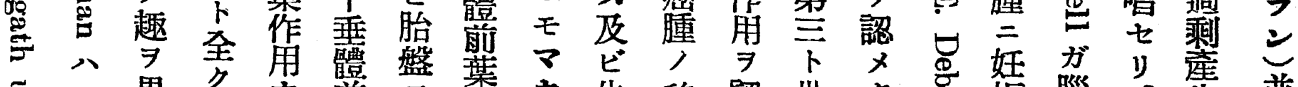

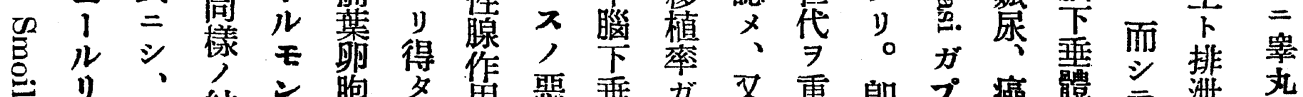

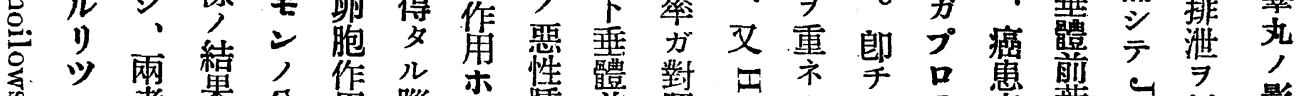

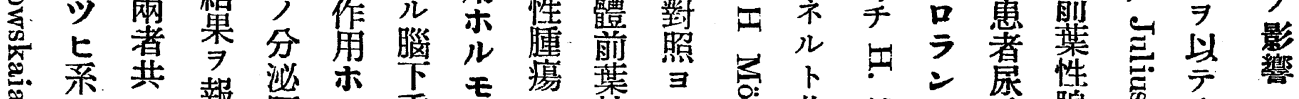

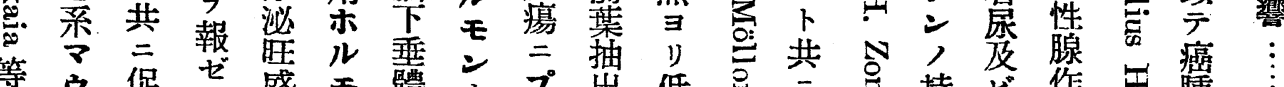

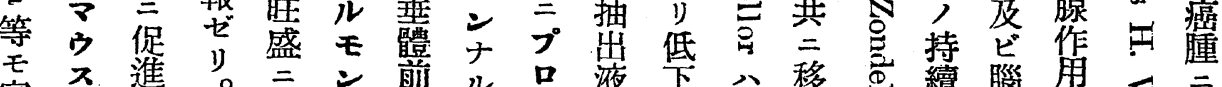

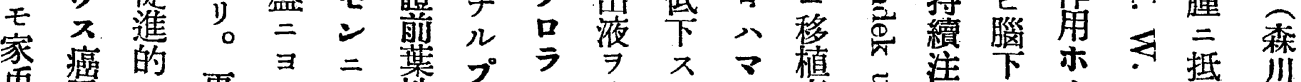

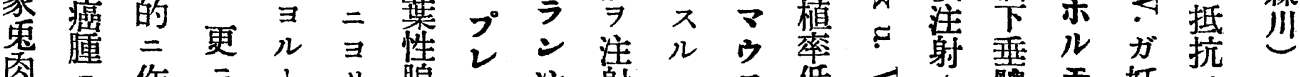
冬三作 三

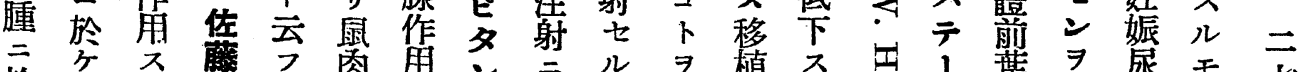
於尔 ル

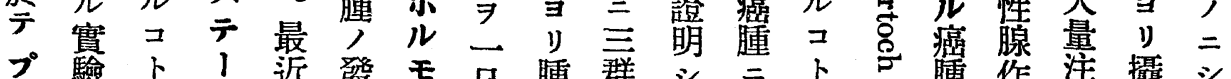

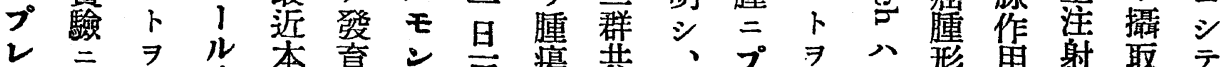

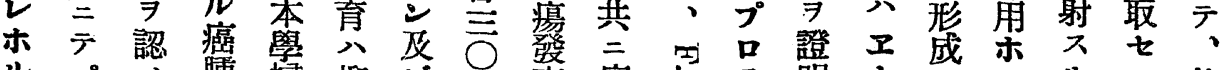

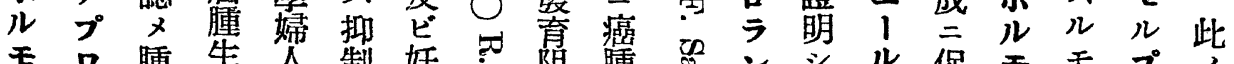

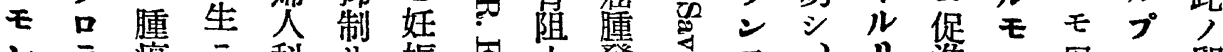

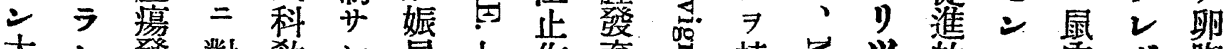

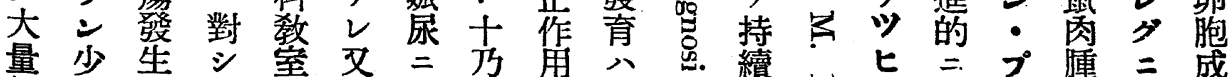

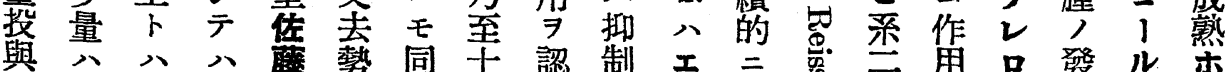




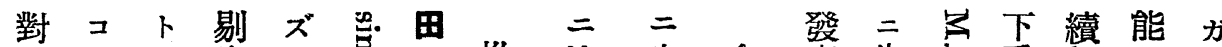

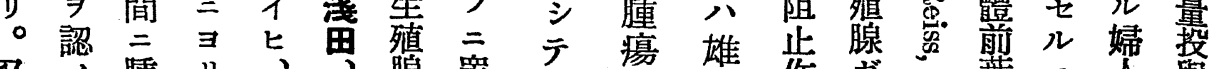

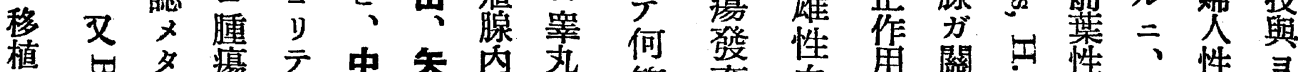

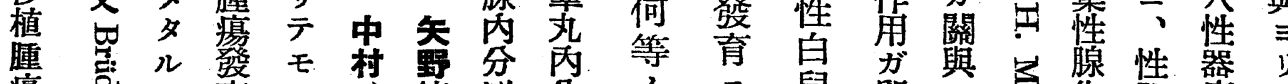

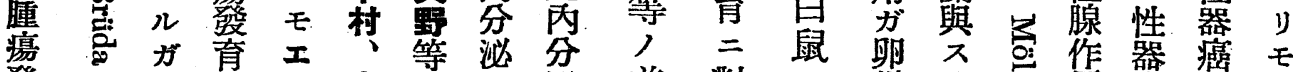

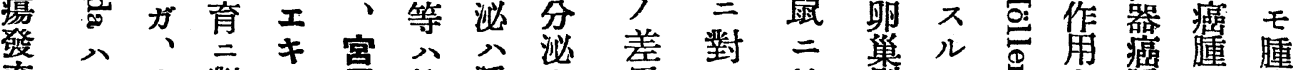

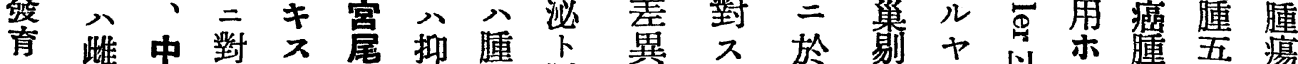
性 村

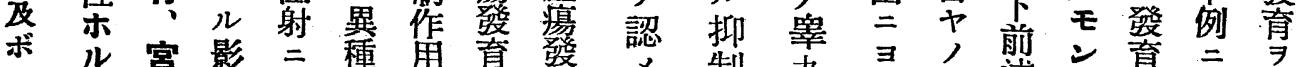

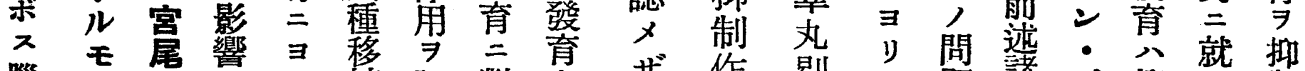

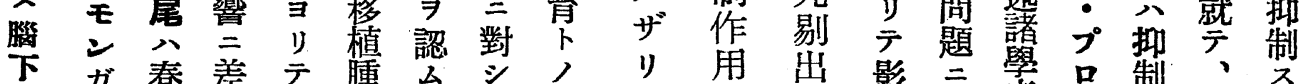

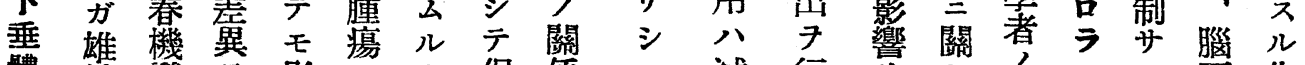
體性發 $\ni$ 影 前 $、$ 動 認響 對ナ隻二

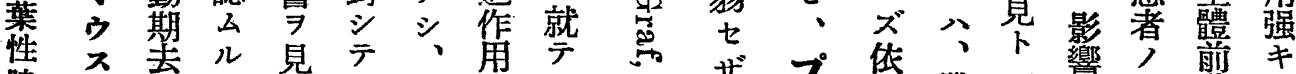
性 覀垒

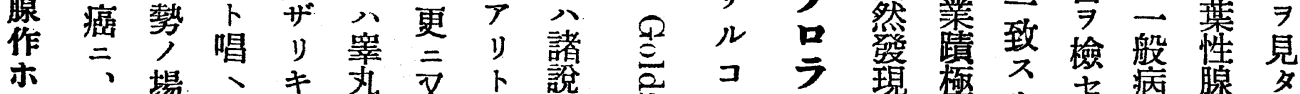

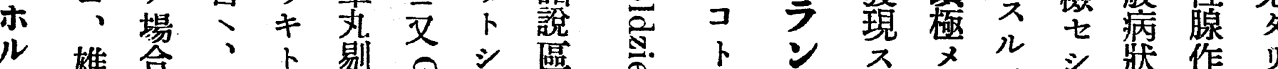

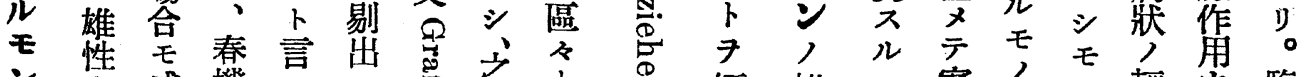
方盛機

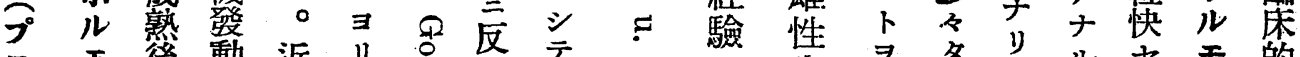

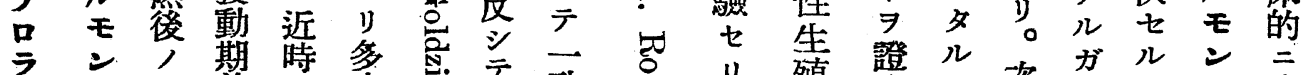

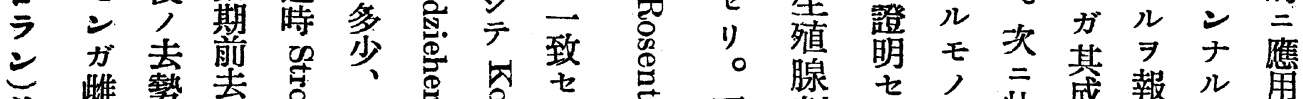

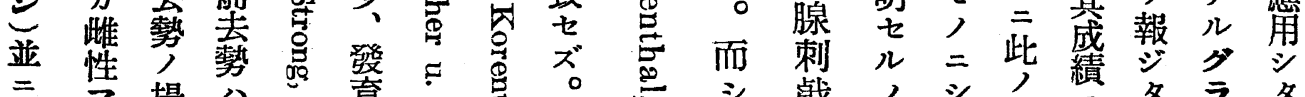

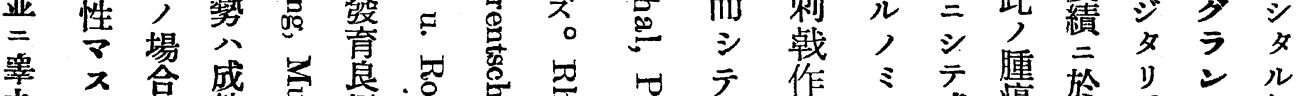

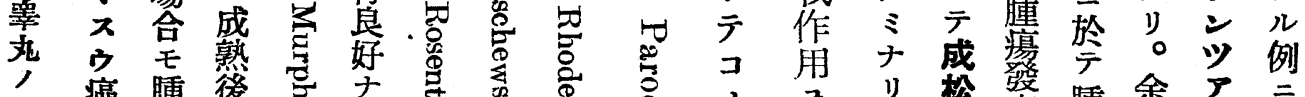

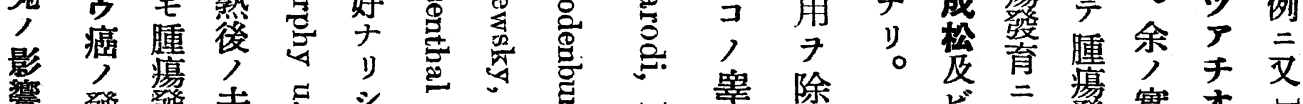

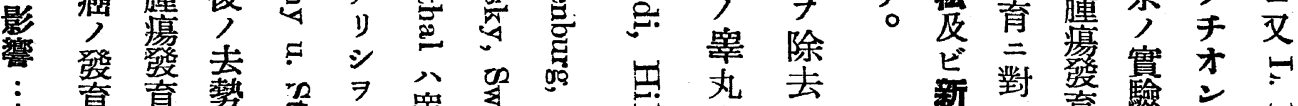

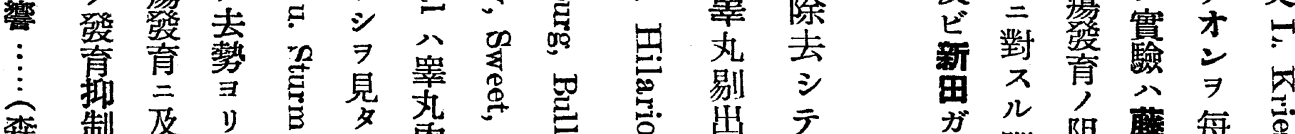

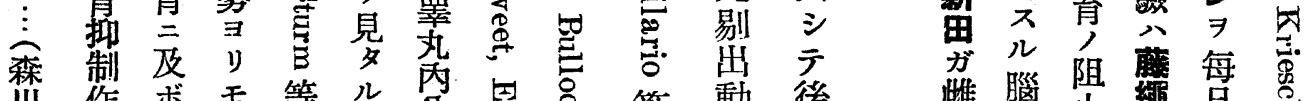

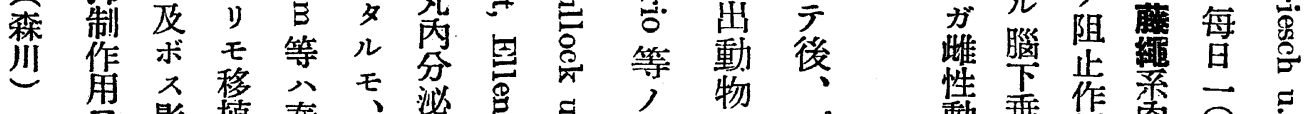

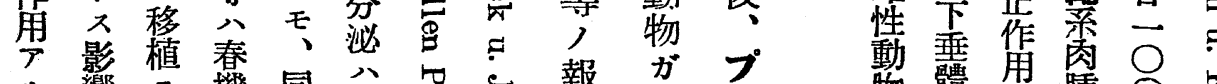
二ル 響

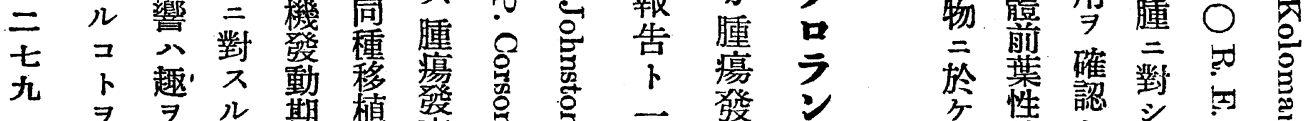
特同抵前䐈篮总导

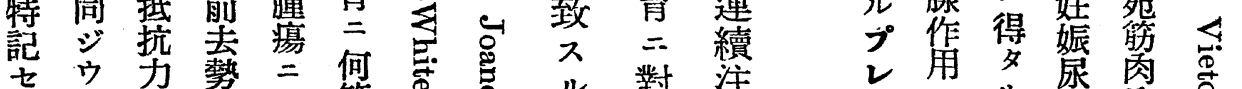

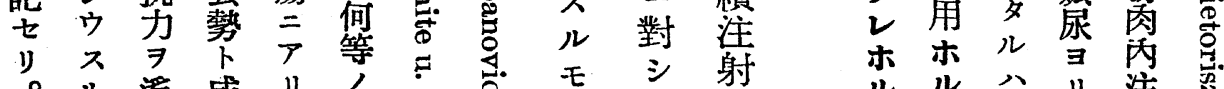

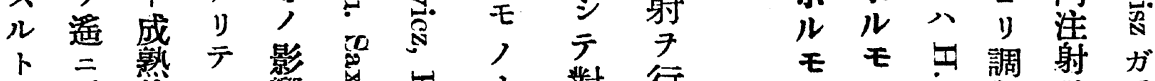

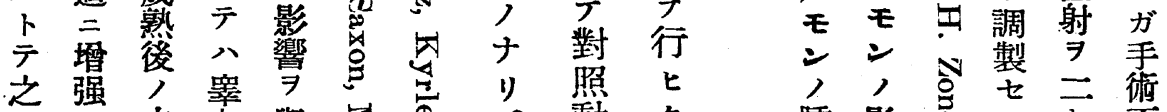

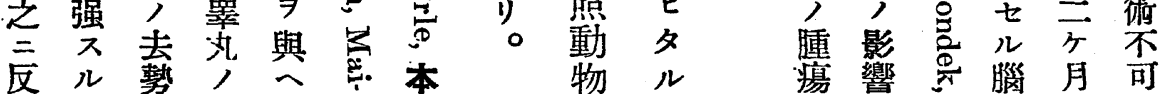




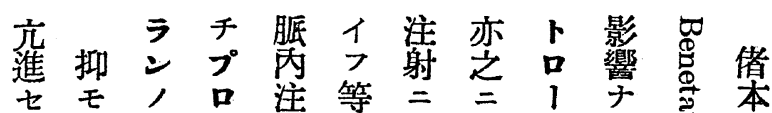

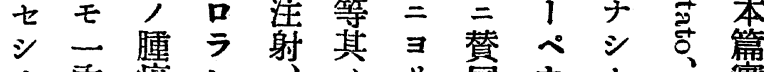

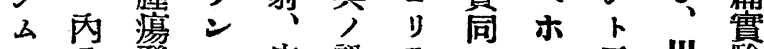
ル分發, 皮說テ厉ル云川驗 卜泌育血下ク公。モ七兄二 共腺抑糖 注所 舞 或

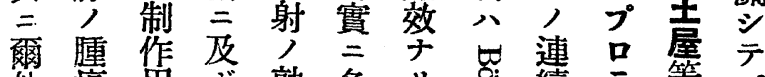

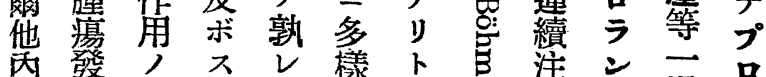

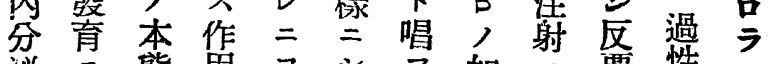

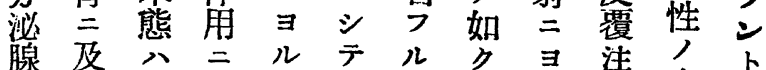

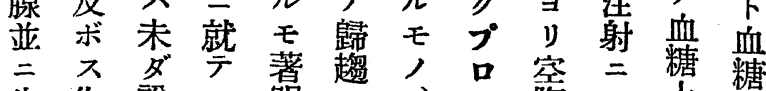

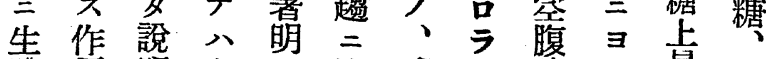

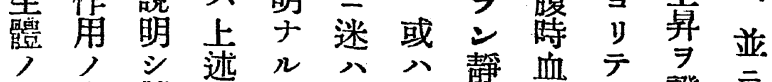

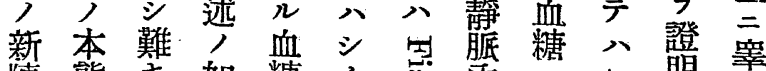

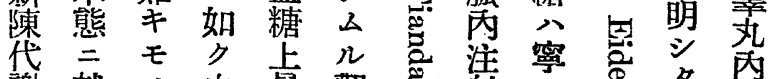

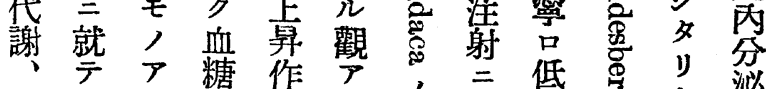
戛、父点角 神給㭆認冤 当示持占血 經與至丈最渦著飞的又續、

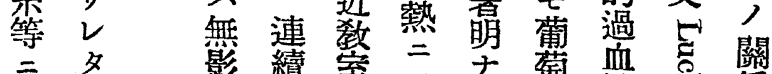

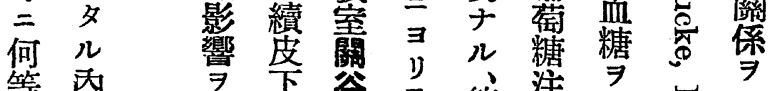

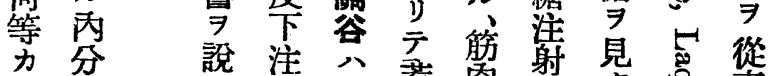

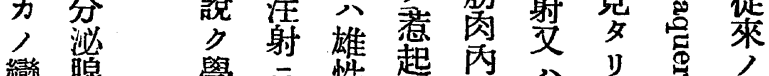

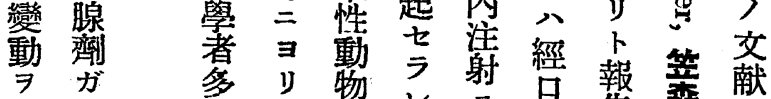
與 腫

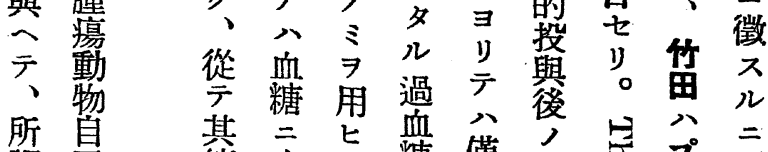

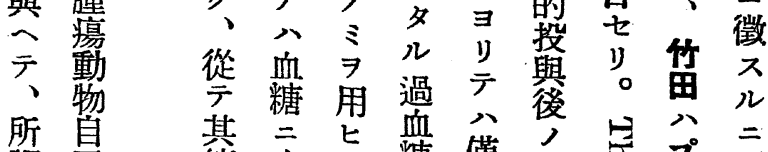

謂芑 基

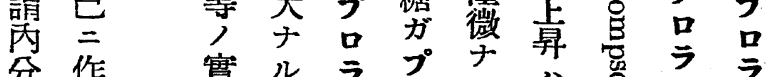

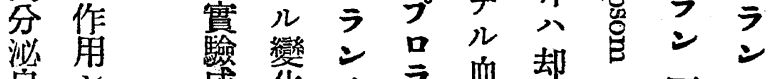
戛 筬花ノ 神該認回二点㙘名注注

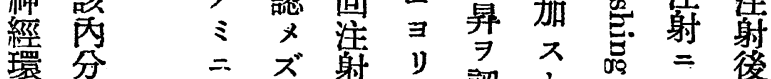

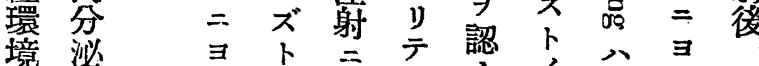

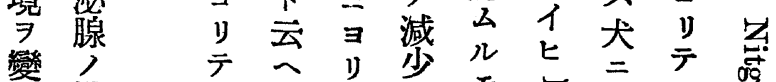

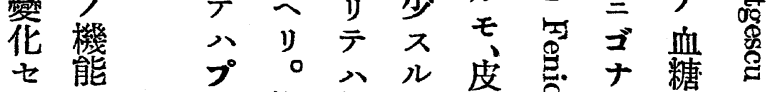

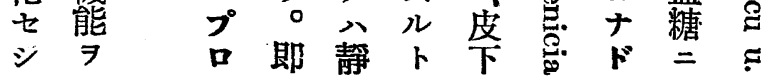

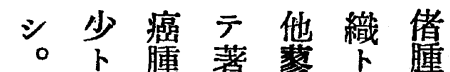
血及沼最瘲

液 ビク・モ發

中家低堀異育

乳鬼尔男学三植

酸肉七江對腫

量腫 ル本點シ 演

人 $=$ 間 $尹$ テ 發

增 於認等 其 糖 育

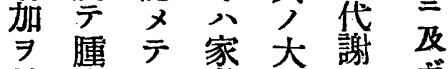

見瘍、蚫鳥齐 ボ

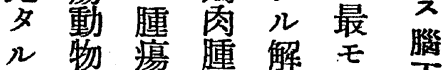

等 = 發三糖 密下

葡育於莋接重

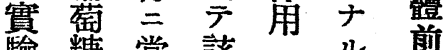

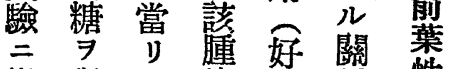

徵與多瘍氮絮性

ス八量 $\exists$ 性 $\Rightarrow$ 腺

ルテ㢳通並有作

点血過三不

明等糖セ㜍ル

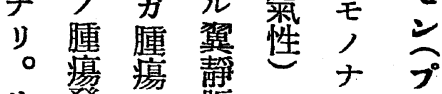

サ發 $=$ 㼣二ル品

レ育攝 血アココラ

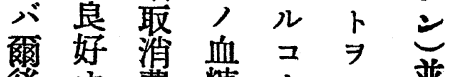

後費 䌅 占實

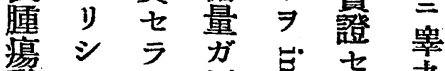

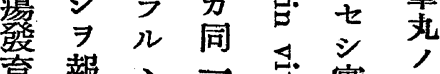

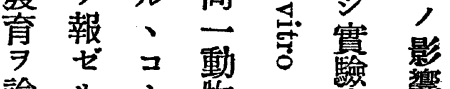

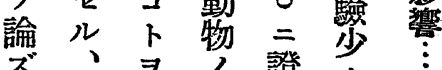

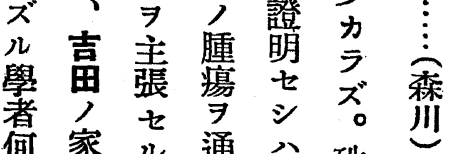

何家萬通實殊

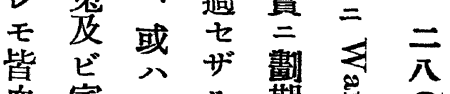

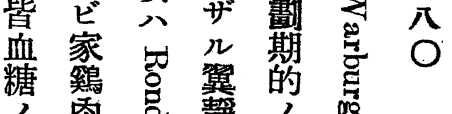

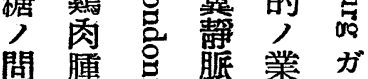

問 腫导. 㟲 業 ガ

題 於加血覧瘇

考宁藤血云組

慮 血 ガ 糖 フ 織

七糖夫量べ

ザ量々 ク 正

ル減鼠些其組 


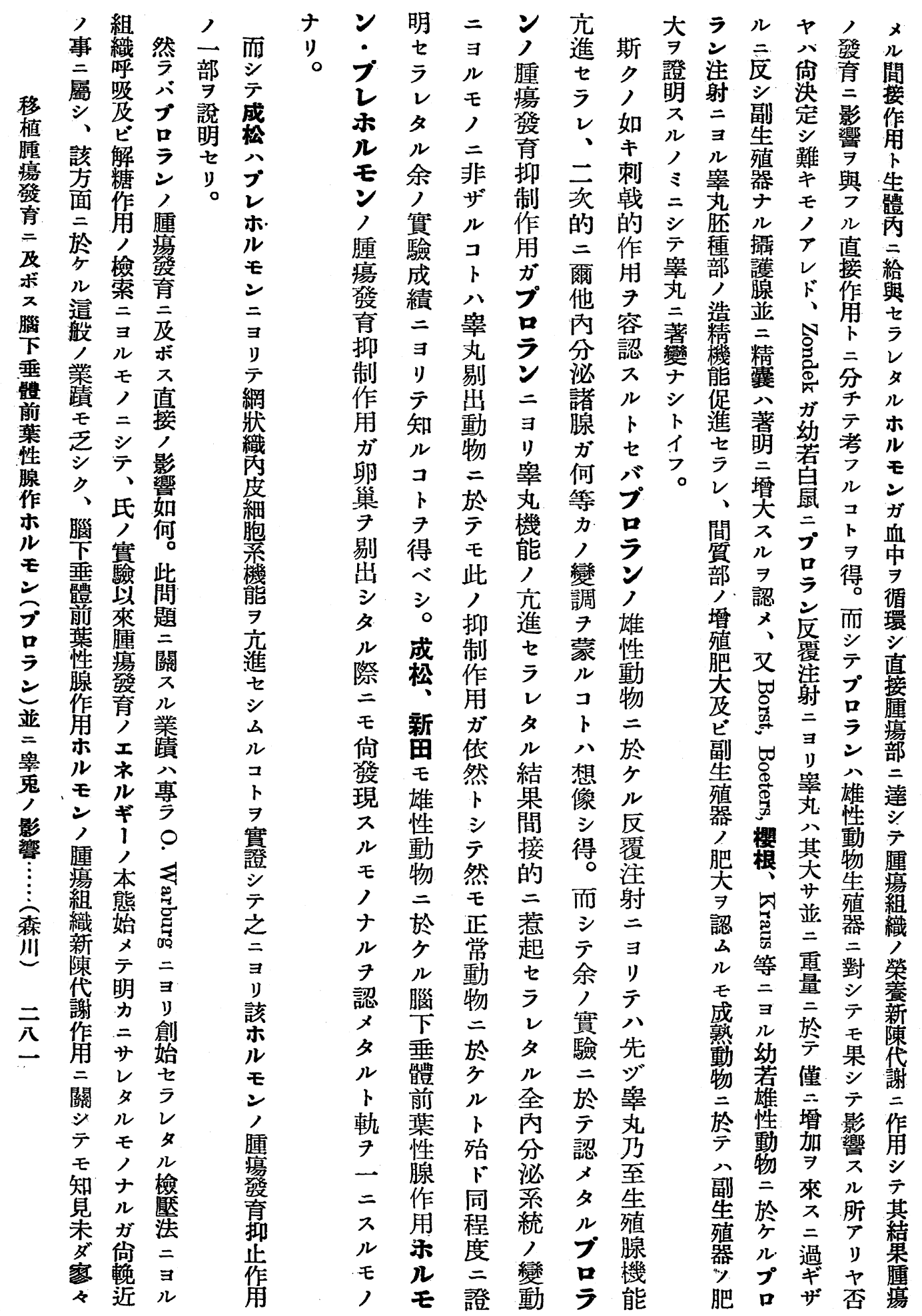




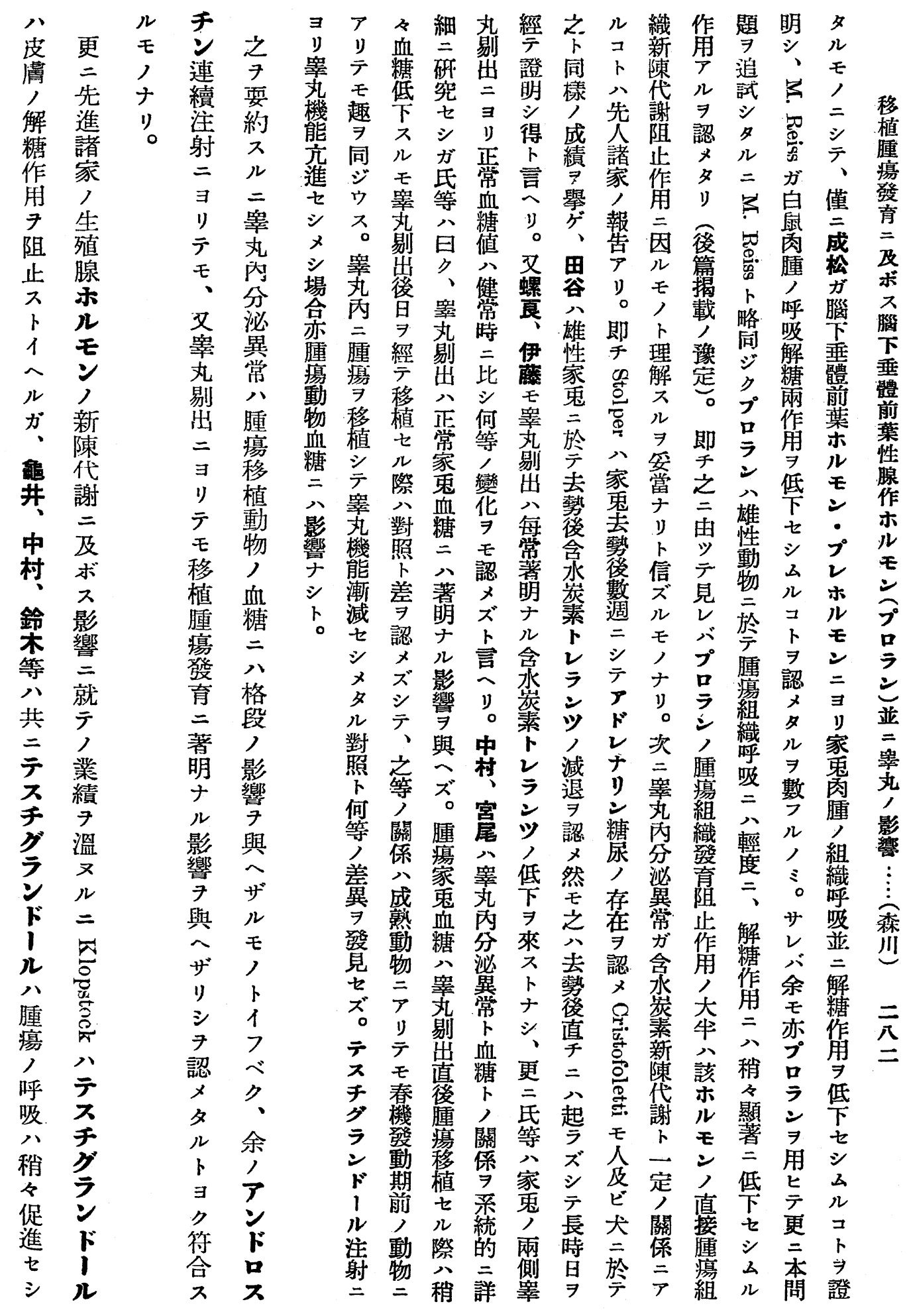




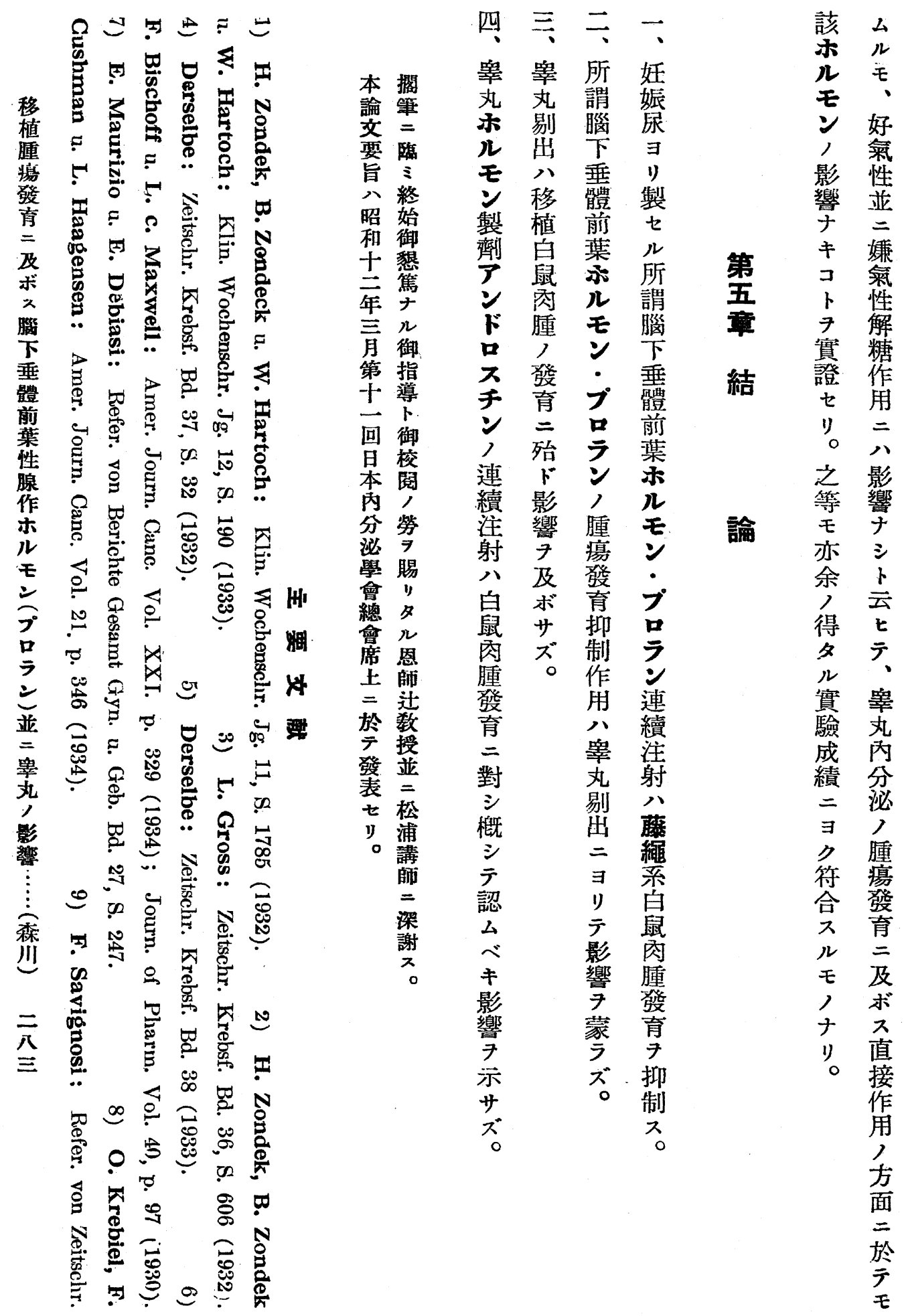




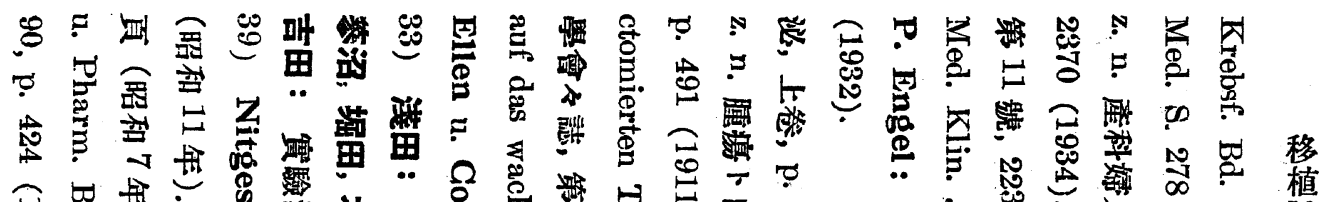

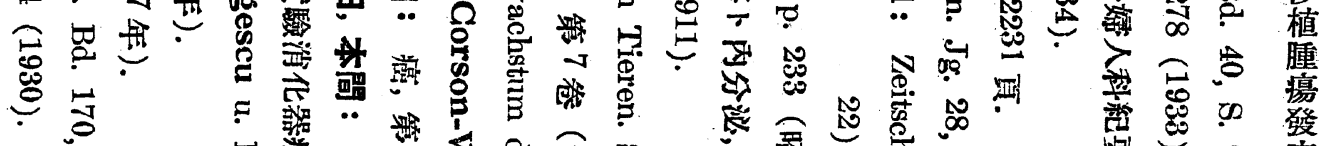

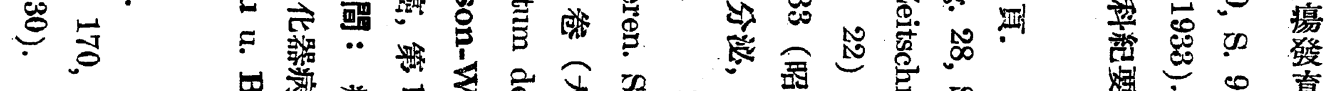

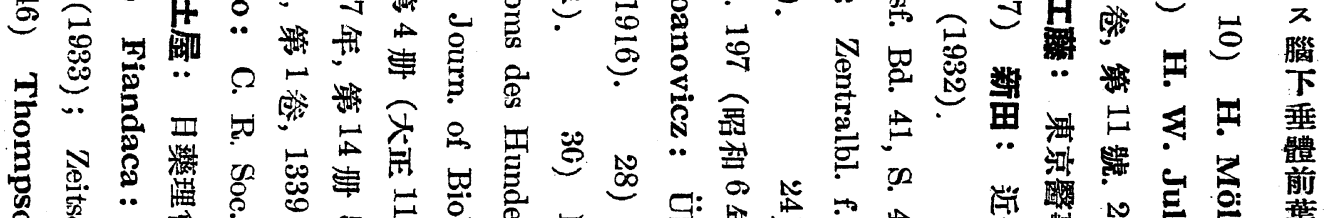

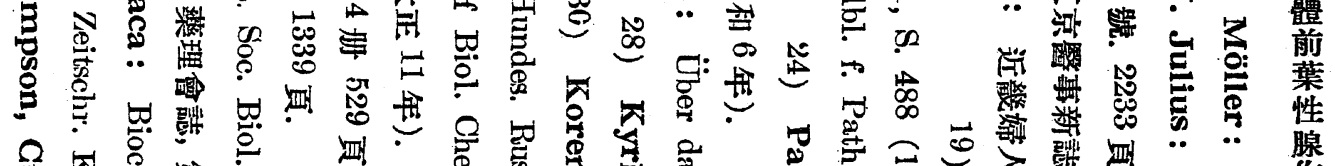

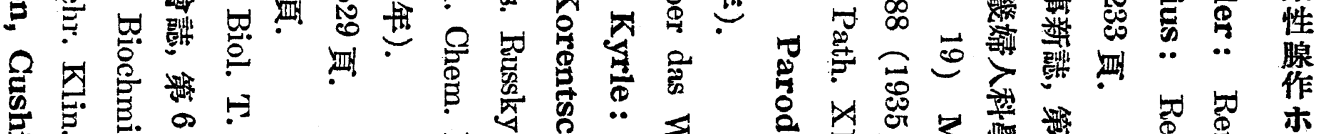

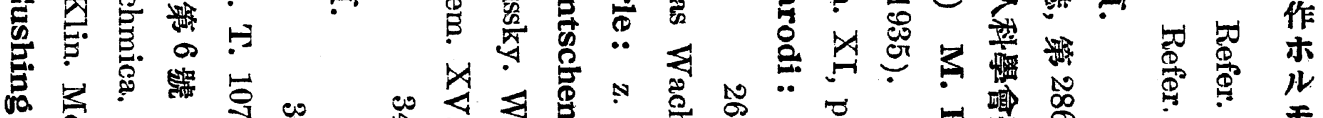

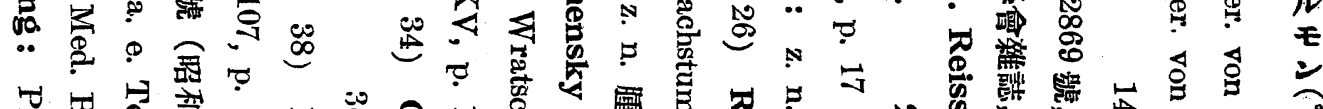

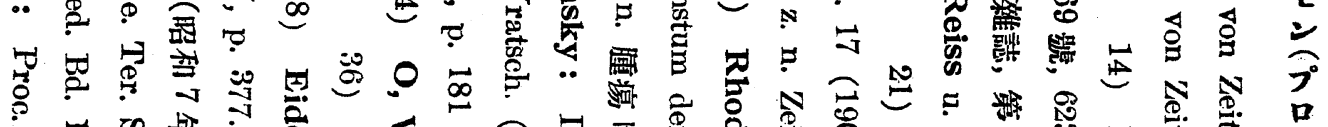

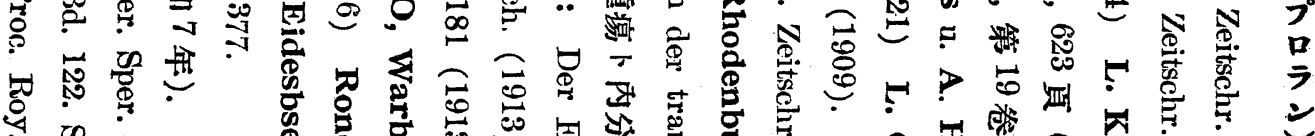

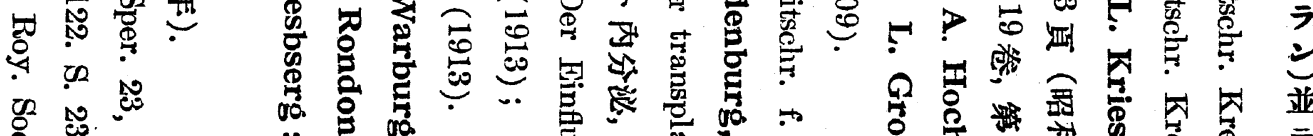

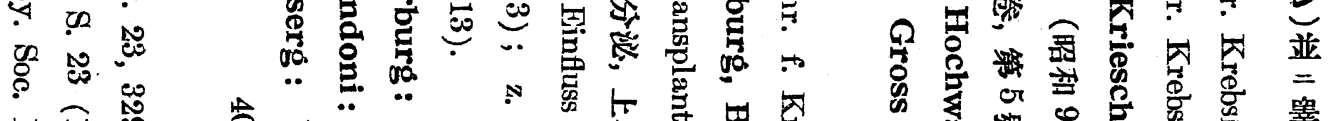

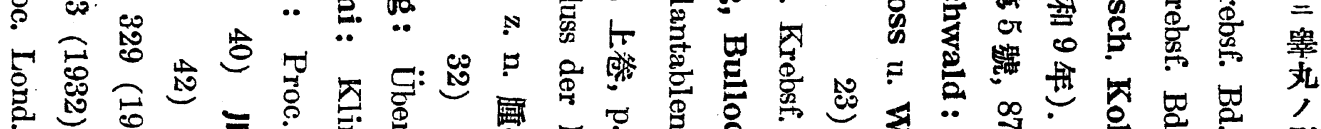

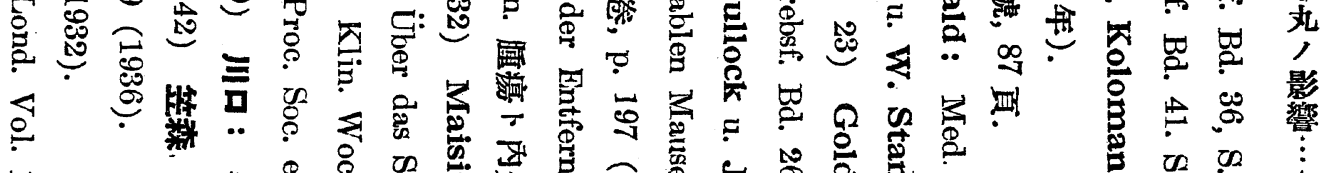

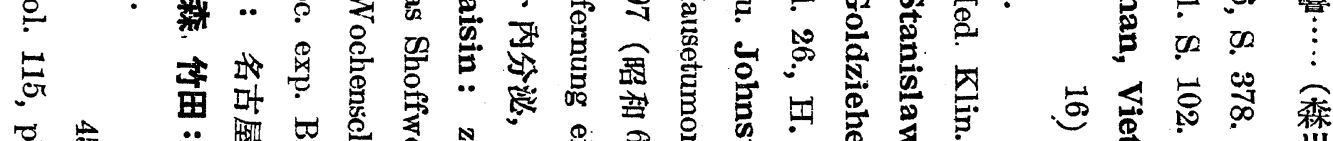

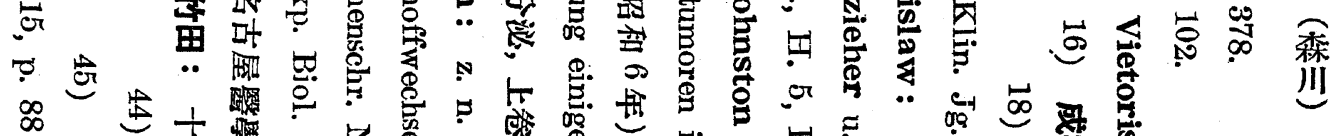

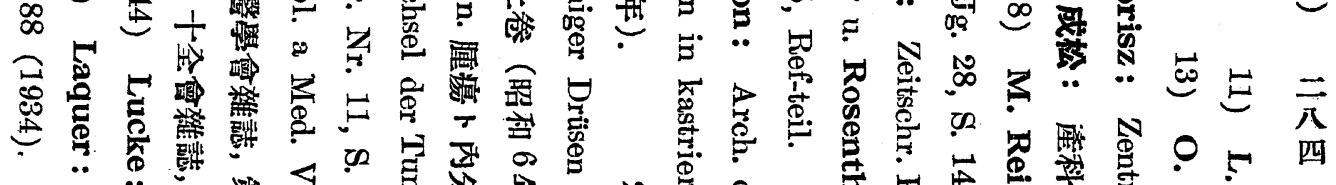

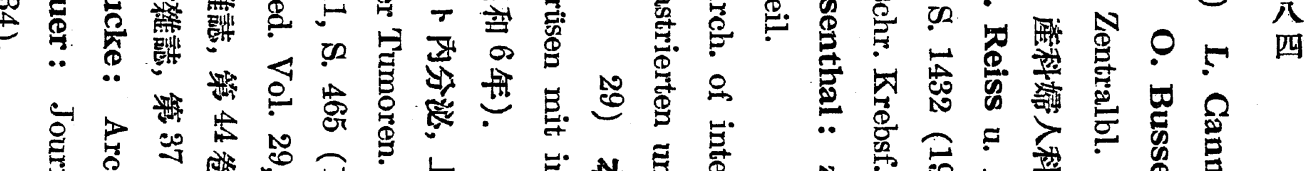

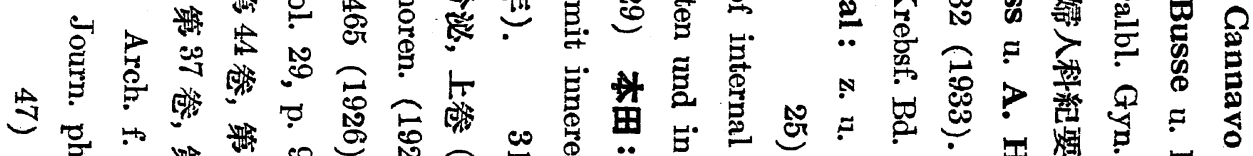

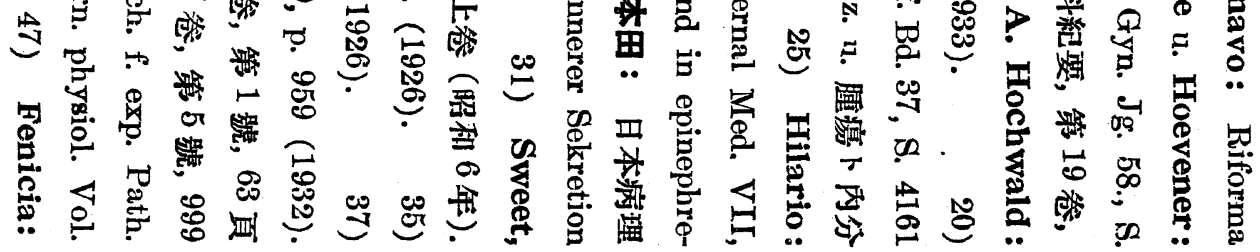




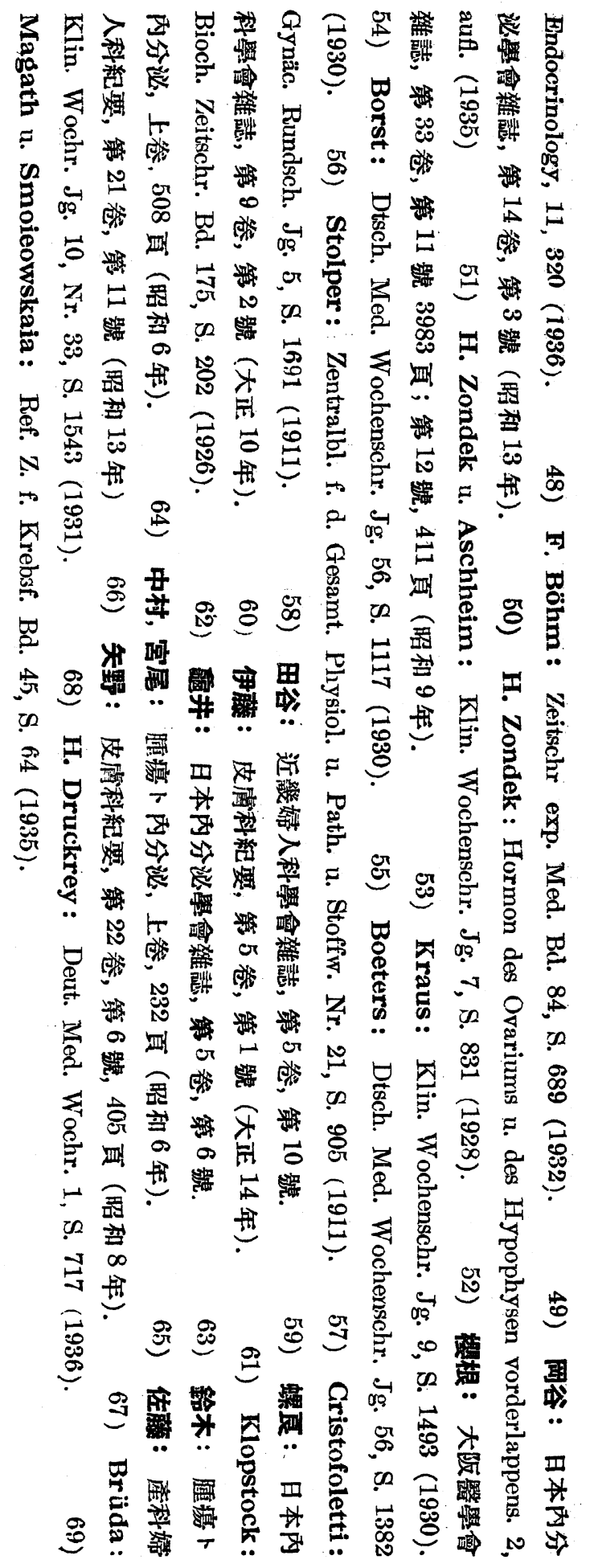


des Rattensarkoms zur Folge.

4) Die Exstirpation des Hodens beeinflusst die Entwicklung des transplantierten Rattensarkoms kaum.

5) Nach der kombinierten Exstirpation des Thymus und des Hodens entwickelt sich das transplantierte Rattensarkom schneller, etwa in demselben Masse wie nach der einfachen Exstirpation der Thymusdrüse.

(Autoreferat)

\title{
Über den Einfluss des Hodens und des gonadtropen Hormons (Prolan) des Hypophysenvorderlappens auf das Wachstum des transplantierten Rattensarkoms.
}

\author{
Von \\ Dr. H. Morikawa.
}

(Áus der 1. Merl. Klinik der Kaiserl. Universität zu Kyoto in Japan. Direkior : Prof. Dr. K. Tsuji)

In dieser Arbeit versuchte der Verfasser, den Einfluss des 17 Tàge lang fortgesetzt injicierten gonadtropen Hormons (Prolan) und des auch ebensolange fortgesetzt injicierten wasserlöslichen Hodenhorinons (Androstin) auf das Wachstum des transplantierten Rattensarkoms klarzustellen. Das gonadtrope Hormon (Prolan) wurde aus dem Harn schwangerer Frauen nach der Zondekschen Alkoholfällungsmethode hergestellt. Die tägliche Injektionsdosis des Prolans entsprach $1.0 \mathrm{ccm}$ Originalurin (nach jemaliger Kontrolle der gonadtropen Wirkung). Die tägliche Injektionsdosis des Androstins war $0.1 \mathrm{ccm}$. Als Versuchstier dienten stets $70-80 \mathrm{~g}$ schwer männliche weisse Ratten. Die Tiere wurden z. T. orchektomiert. Die sonstigen Versuchsanordnungen waren wie beim Versuch 1.. Die Arbeitsergebnisse lassen sich kurz wie folgt zusammenfassen :

1) Die fortgesetzte Injektion des aus dem Urin schwangerer Frauen hergestellten Prolans hemmt das Wachstum des transplantierten Rattensarkoms. 
2) Diese wachstumshemmende Wirkung des Prolans auf das Rattensarkom wird durch die Hodenexstirpation nicht beeinflusst.

3) Auf das Wachstum des transplantierten Rattensarkoms übt die Hodenexstirpation keinen wesentlichen Einfluss aus.

4) Die fortgesetzte Injektion des Hodenhormons, "Androstin" ist ohne nennenswerten Einfluss auf das Wachstum des transplant:erten Rattensarkoms.

(Autoreferat)

\title{
Experimentelle Untersuchungen über den Einfluss \\ verschiedener endocriner Störungen auf die \\ Wirkung des gonadtropen Hormons \\ des Hypophysenvorderlappens.
}

I. Mitteilung.

Beziehung des gonadtropen Hormons zur Schilddrüse.

\author{
Von \\ Dr. Y. Yamao. \\ (Aus der 1. Med. Klinik der Kaiserl. Universität zu Kyoto in Japan. \\ Direktor: Prof. Dr. K. Tsuji)
}

Der Verfasser hat versucht festzustellen, wie die Wirkung des aus dem Urin der Schwangeren hergestellten gonadtropen Hormons des Hypophysenvorderlappens auf das Ovarium durch die Funktionsanomalien verschiedener endocriner Organe, nämlich der Schilddrüse, der Nebenniere, des Thymus und der Milz, beeinflusst wird. Weiter hoffte er, mit Hilfe der Ergebinsse die Beziehungen der genannten endocrinen Organe zum Ovarium feiner analysieren zu können. Die 1. Mitteilung betrifft den Versuch hinsichtlich der Schilddrüse. Dass die Schilddrüse und das Ovarium sich im biologischen Sinne gegenseitig beeinflussen, ist sicher, über das we bestehen jedoch noch viele Meinungsverschiedenheiten.

Die Versuchsanordnung: Als Versuchstiere dienten $30-40 \mathrm{~g}$ schwere junge weibliche weisse Ratten. Das Tier wurde entweder zunïchst thyreoidektomiert oder mit getroeknetem Rinderschilddrüsen- 